\title{
18. Söylem Göstergebilimi: Yazınsal anlatılarda sözcelemeden sözceye anlamlama süreçleri
}

Murat KALELIOĞLU'

APA: Kalelioğlu, M. (2021) Söylem Göstergebilimi: Yazınsal anlatılarda sözcelemeden sözceye anlamlama süreçleri. RumeliDE Dil ve Edebiyat Araştırmaları Dergisi, (Ö9), 204-228. DOI: 10.29000/rumelide.981534.

$\ddot{0} \mathbf{z}$

Temel inceleme alanı anlam ve anlamlama olan göstergebilim kuramı geçmişte kapalı ve durağan yapıların çözümlenmesinde kullanılırken günümüzde iletişim temelli devingen yapıların incelenmesinde de kullanılmaktadır. Göstergebilim kuramı, söylemsel yapıların çözümlenmesinde başvurulan yaklaşım biçimlerini kendi çalışma ve inceleme alanı içinde görmektedir. Bu bağlamda kuram, anlatısal yapıların yanında gerçek bağlamdaki söylemi de inceleme konusu olarak değerlendirmeye başlamıştır. Bu da kuramın, varolan diğer incelemelerin yanında, söylem göstergebilimine doğru evrildiğini göstermektedir. Bu durum, anlatı göstergebiliminin haricinde bir söylem göstergebilimi alanının ortaya çıkmasını sağlamıştır. Bu dönüşümsel sürecin önemli gerekçelerinden biri de göstergebilim kuramının insanla insan ve insanla doğa arasında iletişim amacıyla üretilen her türden bildiriyi farklı aşamalarda anlamlama arzusudur. Buradaki aşamalardan kasıt söylemin oluşmasına katkıda bulunan sözceleme süreçleridir. Bu bakımdan sözceleme ve söylem kuramlarının göstergebilim kuramı ile ilişkisi bu çalışma için disiplinlerarası bir bakış açısını varsaymaktadır. Göstergebilimsel çerçevede söyleme dönüşmüş bir yapının durağanlığından, kapalılığından ya da sınırlılığından söz etmek ve bu yapıyı inceleme nesnesi olarak ele almak olasıdır. Ancak bu araştırma açısından, asıl konu böyle bir dönüşümün nasıl gerçekleştiği, söylemsel yapının hangi anlam katmanlarında nasıl bir süreçten geçtiği ve yapının hangi koşulların sonucunda anlamlı bir bütün haline geldiği önemlidir. Bu yüzden, bu araştırma makalesinde yazınsal bir yapıtta söylemi kuran ögelerin izleri, disiplinlerarası bir anlayışla, söylem göstergebilimi çerçevesinde sürülecektir.

Anahtar kelimeler: Dilbilim, göstergebilim, söylem göstergebilimi, sözceleme, sözce, söylemsel yapılar

\section{Semiotics of Discourse: Signification process from enunciation to utterance in literary narratives}

Semiotics theory, whose main area of study is the meaning and signification of signs, has been used to analyse closed and stationary structures in the past, whereas it is also used in the analysis of communication-based dynamic structures recently. The theory accepts various approaches applied in the analysis of discursive structures within its study field. In this respect, this signification theory regards a wide range of discourses produced in real context as the study subject as well as the narrative structures. This shows the theory's revolutionary evolution towards the semiotics of discourse, which led to the emergence of the semiotics of discourse apart from the narrative semiotics. One of the most critical reasons for this transformational process is the desire of semiotics to interpret all kind of messages produced with the purpose of communication among human beings and between human and nature at different stages. What is meant by the stages here are the enunciation processes that contribute to the formation of discourse. The relationship between enunciation and discourse theories with the

1 Dr. Öğr. Üyesi, Mardin Artuklu Üniversitesi, Yabancı Diller Yüksekokulu, Mütercim Tercümanlık Bölümü (Mardin, Türkiye) kalelioglu.murat@gmail.com. ORCID ID: 0000-0002-8037-3792. [Araştırma makalesi, Makale kayıt tarihi: 05.05.2021-kabul tarihi: 20.08.2021; DOI: 10.29000/rumelide.981534]

Adres

RumeliDE Dil ve Edebiyat Araştırmaları Dergisi Osmanağa Mahallesi, Mürver Çiçeği Sokak, No:14/8 Kadıköy - ISTANBUL / TÜRKIYE 34714 e-posta: editor@rumelide.com tel: +90 $5057958124,+902167730616$
Address

RumeliDE Journal of Language and Literature Studies

Osmanağa Mahallesi, Mürver Çiçeği Sokak, No:14/8

Kadıköy - ISTANBUL / TURKEY 34714

e-mail: editor@rumelide.com,

phone: +90 5057958124, +90 2167730616 
semiotics theory assumes an interdisciplinary perspective for this study. It is possible to mention the stability, closeness, or limitedness of a structure, turned into discourse, and consider it as a study object. However, the main issue is how such a transformation occurs, in which semantic strata the discursive structure goes through, and under which circumstances this structure becomes a meaningful whole in terms of this research. For this reason, the traces of the elements that construct the discourse in a literary work will be traced within the framework of the semiotics of discourse in this research paper.

Keywords: Linguistics, semiotics, semiotics of discourse, enunciation, utterance, discursive structures

\section{Giriş}

Edebi metin incelemesinde kanıtlayıcı ve güvenilir bulgulara ulaşmak yönteme dayalı, incelikli ve sistemli bir çabayı gerektirir. Bunun en önemli nedenlerinden biri metindeki kurgunun inşası sürecinde yazarın okuyucu için ürettiği ve ilk bakışta algılanan bildirinin anlamının altında yatan örtük anlamın ortaya çıkarılmasının gerekliliğidir. Bir diğer önemli neden ise anlamlı bir bütün olarak metnin anlam evreninin hangi aşamalarda nasıl kurulduğunu, yani metnin işleyiş biçimini gözler önüne sermektir. Kurgusal özelliğe sahip edebi metinleri değişik yöntem ve yaklaşımlar ile incelemek olasıdır. Ancak söz konusu bu tür metinlerdeki anlamın ve bu anlamın üretilmesinde izlenilen yolun yapısal düzenlenişini ve bu düzenlenişin temel dayanaklarının neler olduğunu ortaya çıkarmaksa burada göstergebilimden söz etmek gerekir. Bu bağlamda göstergebilimin merkezde olduğu edebi eser incelemelerinde yukarıda belirtilen iki önemli neden birbirini tamamlayıcı niteliktedir.

Bugün göstergebilim denildiğinde, disiplinlerarası çalışmaları destekleyici özelliği ile 21. yüzyılın önemli disiplinleri arasında yerini almış bir disiplinden söz edildiğini söylemek yanlış olmaz. Göstergebilim, önceleri sadece göstergeleri, göstergelerin gerçek dünyadaki karşılıkları (göndergeler) ve yüklendikleri anlamları betimlemeyi amaç edinmiş olan bir yaklaşım iken son zamanlarda özellikle de 1960 lardan sonra kendi gelişimini sürdüren, inceleme nesnesi olarak göstergelerin anlamlı dizilişleri ile değişik disiplinlerde üretilen dizgeleri ve üretim sürecine dahil edilen göstergeleri, göstergelerarası ilişkileri, dizgenin üretiliş biçimi ve anlam üretim süreçlerini incelemeyi amaç edinmiş bir bilim alanına dönüşmüştür. Göstergebilim temel olarak kültürel insanbilim, dilbilim ve olgubilimden beslenmektedir. Göstergebilim, bu temel alanların etkisi altında olan tüm alanlar ile etkileşim halindedir. Tahsin Yücel'in de belirttiği gibi "göstergebilim hem anlamlama üzerine genel bir düşünce sistematiği hem de anlamlı bütünleri çözümleme üzerine geliştirilmiş bir yöntemler bütünüdür" (2015: 127). Merkezinde göstergeler ve görünenden görünmeyene göstergelere ait değişik özelliklerin sistemli anlamlaması olan göstergebilim kendi gelişimi içinde zamanla hem gündelik yaşama hem de bilime ait bir çok temel ve alt dizge ile de doğal bir ilişkiye girmiştir. Bu durum göstergebilim çalışmalarının disiplilerarası hatta disiplinlerötesi olma özelliğine gösterilecek önemli bir kanıt olabilir.

Söz konusu disiplinlerarasılık olunca göstergebilimin uğraş alanının sadece diliçi göstergeler ile üretilen dizgeler olmadığını aksine dilötesi göstergeleri ve bu göstergeler ile üretilen dizgeleri de inceleme alanına dahil ettiğini söylemek mümkündür. Burada önemli bir başarının altını çizmek gerekir. Bu başarı, "göstergebilimin tümce düzeyini aşması ve dildışı göstergelerin çözümlenmesine" (Sığırcı, 2017: 13) önemli katkılar sunmuş olmasıdır. Aslında bu bir gerekliktir. Bu sebeple Ferdinand de Saussure, 20. yüzyılın başlarında verdiği dilbilim derslerinde bu duruma işaret etmiştir: "Göstergelerin toplum yaşamı içindeki yaşamını inceleyecek bir bilim tasarlanabilir: Toplumsal ruhbilime, bunun sonucu olarak da genel ruhbilime bağlanacak bir bilim. Göstergebilim diye adlandıracağız biz bu bilimi. Göstergebilim, göstergelerin ne olduğunu, hangi yasalara bağlandığını öğretecek bize” (1998: 46). Burada önem arz eden durum

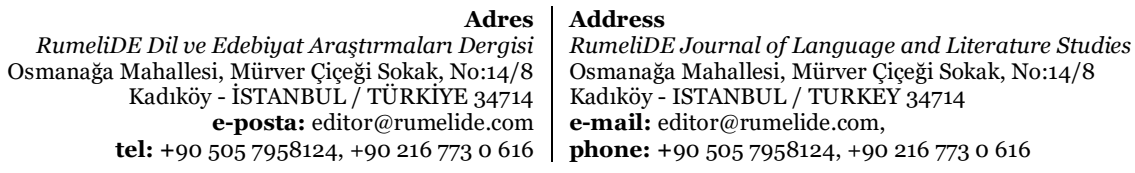


göstergebilimin klasik dil incelemelerinden ayrılarak dilin ötesine geçmesi ve sosyal ve kültürel yaşama ait dizgelerinde incelenmesine olanak tanımasıdır. Bu da bir anlamlama kuramı olarak göstergebilimin bilimlerarası çalışmalar noktasında ilişkide olduğu disiplinlerin artmasına olanak tanımıștır.

Bazı araştırmacılar tarafından daha 1980 lere kadar göstergebilim, kapalı ve durağan yapıları inceleyen bir bilim alanı olarak görülmekte ve eleştirilmekteydi. Ancak sonrasında kuramın inceleme alanına söylemin de dahil edilmesi ile göstergebilim incelemeleri hareketli yapıların çözümlenmesinde de önemli bir yol kat etmiş ve kendisine yöneltilen bu eleştiriler giderek azalmıştır. "Bugün artık anlatı ve söylem göstergebilimi Algirdas Julien Greimas'ın öncülüğündeki bilimsel etkinliklerle büyük aşamalar göstermiştir” (Rifat, 2011: 189). Söylem'e anlamlamanın tümü şeklinde bakan Greimas ve Courtés için "ilk bakışta, söylem kavramı göstergebilimsel süreç kavramıyla özdeşleştirilebilir. Bu şekilde, söylem dilin dizimsel ekseninde yer alan göstergebilimsel olguların (ilişkiler, birimler, işlemler, vb.) bütünü olarak görülür. [...] Diğer yandan da söylem ve metin kavramları kestirim yoluyla ve varsayımsal olarak dildışı göstergesel süreçlerin (söylem ya da metin olarak görülen tören, film, karikatür, vb.) belirtilmesinde kullanılır. Bu terimlerin kullanımı, bu tür dışavurumları destekleyen dizimsel düzenlemenin varlı̆̆ını varsayar" (1982: 81-82). Göstergebilim açısından dil toplumsal ve kültürel bağlamlar içinde incelenir. Dilin bu iki bağlam içinde ele alınması da söylem'e ulaşmayı mümkün kılar. "Söylemin dildışı göstergelerle olan ilişkisi de açıktır. Bu çerçevede göstergebilimin sadece disel yapıları çözümlemekle kalmadığı, belirli bir söylem içinde anlamın inşasına katkıda bulunan her türlü yapıyı çözümlemeyi amaçladığı" (Günay, 2013: 102) söylenebilir.

Söyleme ulaşmayı amaç edinmiş bir göstergebilimden söz etmek demek sözceleme kuramının eklemlendiği bir söylem göstergebiliminden söz etmek demektir. 'Göstergebilim yalnızca metindeki sözcelemenin 'kişisel' temsilleri (anlatıcı, gözlemleyen, vb.) ile yetinmez, yanısıra sözceleme edimine ve sözcelemsel işlemlere de yer vererek tümüyle bir söylem göstergebilimine dönüşür” (Günay, 2018: 58). Söylem göstergebilimi inceleme sürecinde sözceye hareketlilik kazandıran sözcelemenin oluşum süreçlerine, sözcelemeyi kuran oluşturucu ögelere ve birbiriyle ilişkili olan bu ögelerin anlamsal işlevlerine yönelir. Bu çalışmanın araştırma nesnesi Tahsin Yücel'in Mutfak Çıkmazı adlı romanıdır. Çalışma boyunca romanın hangi anlam katmanında nasıl sözceye/söyleme dönüştüğü ve anlamlı bir bütün haline geldiği söylem göstergebilimi çerçevesinde araştırılacaktır. Araştırma sırasında metin, anlatı ve öykü gibi değişik anlam katmanlarındaki sözce ve sözceleme edimi bağlamlarında metnin oluşmasına katkıda bulunan ögelere ve sayısal verilerine de yer verilecektir.

\section{Çözümleme}

Bu kısımda çalışma (a) metnin yapısal düzenlenişi, (b) sözceleme durumu ve (c) sözce öznesinin iletişimdeki yeri olarak üç alt başlıkta gerçekleştirilecektir. Çözümlemenin ilk aşamasında Mutfak Çıkmazı romanının yapısal anlamda nasıl düzenlendiği, ikinci aşamasında romanın sözceleme durumu, üçüncü aşamasında ise metnin kurgu düzleminin oluşturucu bir ögesi olan öykü düzleminde geçen konuşmaların (üretilen sözcelerin) sıklığı irdelenecektir.

\section{a. Metnin yapısal düzenlenişi}

Bir metnin, özellikle de roman türünde çok sayfalı bir metnin, yapısal düzenlenişini bilmek incelemenin sonraki aşamalarında birçok açıdan kolaylık sağlayacaktır. Bu durum metin içinde yapılan ve çalışmada kullanılması planlanan bazı önemli ip uçlarının tespiti, yerleştirildiği yerler ve bunların kullanım aşamasına gelidiğinde ulaşılması vb. durumlar bu kolaylıkların bazılarıdır. Ayrıca her metnin kurgulandığı içerik düzenlemesi ilgili metnin yapısal işleyişi ile de yakından ilintilidir. Burada metnin yapısal düzenlenişi içinde

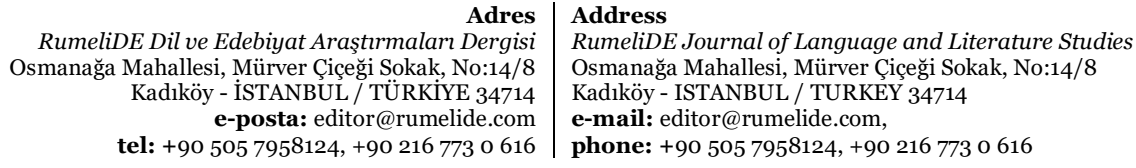


birbiriyle ilişkili, çalıştırılmayı bekleyen bir takım çarklardan söz etmek olasıdır. Bu çarklar Umberto Eco'nun benzetmesindeki tembel ve işletilmesi gereken bir makinanın çarkları olarak da düşünülebilir. Bu çarkların işlevselik kazanması açısından ilk incelemenin romanın genel düzenlenişi hakkında yapılması olasıdır. Bu çalışmanın inceleme nesnesi olan Mutfak Çıkmazı ilk yayımlandığı tarih olan 1960 dan bu yana altıncı baskısını yapmıștır. Bu çalışmada kullanılacak baskı 2020 de çıkarılan altıncı baskıdır.

\begin{tabular}{|l|l|l|}
\hline Bölüm & Sayfa & Bölüme ait toplam sayfa sayısı \\
\hline I & $13-28$ & 16 \\
\hline II & $29-39$ & 11 \\
\hline III & $40-49$ & 10 \\
\hline IV & $50-64$ & 15 \\
\hline V & $65-74$ & 10 \\
\hline VI & $75-85$ & 11 \\
\hline VII & $86-97$ & 12 \\
\hline VIII & $98-106$ & 9 \\
\hline IX & $107-113$ & 7 \\
\hline X & $114-123$ & 10 \\
\hline XI & $124-130$ & 7 \\
\hline XII & $131-144$ & 14 \\
\hline
\end{tabular}

Tablo 1. Mutfak Çıkmazı romanının bölüm ve sayfa düzeni

Tablo 1'in ilk sütununda romanın on iki bölümden oluştuğu, ikinci sütununda her bir bölümün konumlandırıldığı sayfa numaraları, son sütununda ise her bölüme ayrılan sayfa toplamı görülmektedir. Tabloda verilmeyen ilk on iki sayfa kapak sonrası kimlik bilgileri ve sunuş kısmına ayrılmıştır. Tabloda da belirtildiği gibi anlatı on üçüncü sayfadan itibaren başlamaktadır. Tablodaki sayfa dağılımından da anlaşılacă̆ı üzere bölümlerin yerleştirildiği sayfa miktarı birbirinden farklıdır. Bu yüzden bölümlerin, sayfa dağılımlarının kurgulanmasında oulipo benzeri bir yaklaşımda olduğu gibi algoritmik bir yapı ya da hesaplamanın olduğu görülmemektedir.

Tablonun ilk iki sütununda bölüm ve sayfa sıra sayıları doğal olarak belirli bir düzen içinde birbirini takip ederken üçüncü sütunda bölümlere ayrılan toplam sayfa sayılarının dağılımında bir düzensizlik gözlemlenmektedir. Tabloda her bir bölüme ait toplam sayfa sayısında düzensiz farklılık bulunmaktadır. Örnek olarak ilk bölüme ayrılan sayfa miktarı (16) iken ikinci bölümde bu bu miktar düşmekte (11), bir sonraki bölümde tekrar düşmekte (10) ve sonrasında da artmaktadır (15). Romanın bölümlere ayrılan toplam sayfa sayısında bir sisteme bağlanmadığı düşünülen iniş çıkışlarla karşıllaşılmaktadır.

Bu durum iliş̧isel değerlerin içinde olduğu bir gösterimle detaylandırılabilir. Bu gösterimde (<) göstergesi ilk kullanılan sayının sonrakine oranla küçüklüğünü, (>) göstergesi ilk sayının sonrakinden büyüklüğünü, (=) göstergesi ilgili sayılı sayfada verilen ve satır sayıları ile belirtilen boşluğun diğer sayfa(lar)daki boşluklarla eşit oranda olduğunu, ( $\neq$ ) göstergesi de ilgili sayılı sayfada verilen ve satır sayıları ile belirtilen boşluğun diğer sayfa(lar)daki boşluklarla eşit olmadığını göstermek için kullanılacaktır:

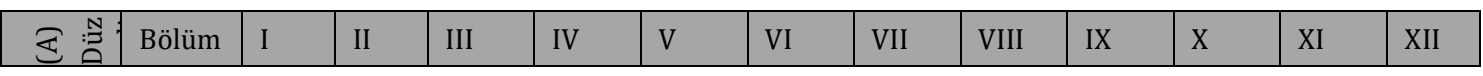

Adres

RumeliDE Dil ve Edebiyat Araştırmaları Dergisi Osmanağa Mahallesi, Mürver Çiçeği Sokak, No:14/8 Kadıköy - ISTANBUL / TÜRKIYE 34714 e-posta: editor@rumelide.com tel: +90 $5057958124,+902167730616$
Address

RumeliDE Journal of Language and Literature Studies

Osmanağa Mahallesi, Mürver Çiçeği Sokak, No:14/8

Kadıköy - ISTANBUL / TURKEY 34714

e-mail: editor@rumelide.com,

phone: +90 5057958124, +90 2167730616 


\begin{tabular}{|c|c|c|c|c|c|c|c|c|c|c|c|c|c|}
\hline & $\begin{array}{l}\text { Sayfa } \\
\text { sayısı }\end{array}$ & $\begin{array}{l}13< \\
28\end{array}$ & $\begin{array}{l}29< \\
39\end{array}$ & $\begin{array}{l}40< \\
49\end{array}$ & $\begin{array}{l}50< \\
64\end{array}$ & $\begin{array}{l}65< \\
74\end{array}$ & $\begin{array}{l}75< \\
85\end{array}$ & $\begin{array}{l}86< \\
97\end{array}$ & $\begin{array}{l}98< \\
106\end{array}$ & $\begin{array}{l}107 \\
< \\
113\end{array}$ & $\begin{array}{l}114 \\
< \\
123\end{array}$ & $\begin{array}{l}124 \\
< \\
130\end{array}$ & $\begin{array}{l}131 \\
< \\
144\end{array}$ \\
\hline & $\begin{array}{l}\text { Bölüm } \\
\text { başı } \\
\text { sayfa } \\
\text { boşluk } \\
\text { oranı }\end{array}$ & $\begin{array}{l}13= \\
(11 \\
\text { satir } \\
)\end{array}$ & $\begin{array}{l}29= \\
(11 \\
\text { satır } \\
\text { ) }\end{array}$ & $\begin{array}{l}40= \\
(11 \\
\text { satır) }\end{array}$ & $\begin{array}{l}50= \\
(11 \\
\text { satır) }\end{array}$ & $\begin{array}{l}65= \\
(11 \\
\text { satır) }\end{array}$ & $\begin{array}{l}75= \\
(11 \\
\text { satır) }\end{array}$ & $\begin{array}{l}86= \\
(11 \\
\text { satır) }\end{array}$ & $\begin{array}{l}98= \\
(11 \\
\text { satır) }\end{array}$ & $\begin{array}{l}107= \\
(11 \\
\text { satır) }\end{array}$ & $\begin{array}{l}114= \\
(11 \\
\text { satır) }\end{array}$ & $\begin{array}{l}124= \\
(11 \\
\text { satir) }\end{array}$ & $\begin{array}{l}131 \\
(11 \\
\text { satır } \\
\text { ) }\end{array}$ \\
\hline \multirow{3}{*}{ 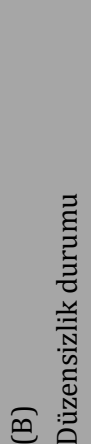 } & $\begin{array}{l}\text { Sayfa } \\
\text { miktar } \\
1\end{array}$ & $16>$ & $11>$ & $10<$ & $15>$ & $10<$ & $11<$ & $12>$ & 9> & $7<$ & $10>$ & $7<$ & 14 \\
\hline & $\begin{array}{l}\text { Değişi } \\
\text { m } \\
\text { oranı }\end{array}$ & $\begin{array}{l}16 \\
\rightarrow\end{array}$ & $-5<$ & $-1<$ & $+5>$ & $-5<$ & $+1=$ & $+1>$ & $-3<$ & $-2<$ & $+3>$ & $-3<$ & +7 \\
\hline & $\begin{array}{l}\text { Bölüm } \\
\text { sonu } \\
\text { sayfa } \\
\text { boşluk } \\
\text { oranı }\end{array}$ & $\begin{array}{l}28= \\
(3 \\
\text { satır } \\
)=\end{array}$ & $\begin{array}{l}39 \neq \\
(3 \\
\text { satır } \\
)<\end{array}$ & $\begin{array}{l}49 \neq \\
(30 \\
\text { satır) } \\
>\end{array}$ & $\begin{array}{l}64 \neq \\
(3 \\
\text { satır) } \\
<\end{array}$ & $\begin{array}{l}74 \neq \\
(20 \\
\text { satır) } \\
>\end{array}$ & $\begin{array}{l}85 \neq \\
(1 \\
\text { satır) } \\
<\end{array}$ & $\begin{array}{l}97 \neq \\
(23 \\
\text { satır) } \\
>\end{array}$ & $\begin{array}{l}106 \neq \\
(12 \\
\text { satır) } \\
>\end{array}$ & $\begin{array}{l}113 \neq \\
(11 \\
\text { satır) } \\
<\end{array}$ & $\begin{array}{l}123 \neq \\
(25 \\
\text { satır) } \\
>\end{array}$ & $\begin{array}{l}130 \neq \\
(7 \\
\text { satır) } \\
<\end{array}$ & $\begin{array}{l}144 \\
(29 \\
\text { satır } \\
\text { ) }\end{array}$ \\
\hline
\end{tabular}

Tablo 2. Mutfak Çıkmazı romanının yapısal düzenlenişinde düzenlilik/düzensizlik durumu

Tablo1'deki genel durumdan hareketleTablo 2'de Mutfak Çıkmazı romanının yapısal düzenlenişi ile ilgili karşıt bir durumun söz konusu olduğu varsayılabilir. Bu karşıtlık tabloda (A düzenlilik) / (B düzensizlik) olarak iki farklı grupta belirtilmiştir.

Tablonun ilk bölümüne (A) bakıldı̆̆ında ilk olarak belirli bir sıralama düzenine sahip olan bölümler ile karşılaşılır. Bu bölümler roma rakamları ile gösterilmiştir $(\mathrm{I}<\mathrm{II}<\mathrm{III}<\mathrm{IV}<\mathrm{V}<\mathrm{VI}<\mathrm{VII}<\mathrm{VIII}<\mathrm{IX}<\mathrm{X}<\mathrm{XI}<$ XII). Bu düzenliliğe dahil olan yapısal unsurların bir diğeri de sayfa sayısı satırında görülmektedir. Sayfa sayıları kendi doğal düzeni içinde metindeki bölümlemenin akış sırasına göredir. Bu durumda tıpkı bölümlerde olduğu gibi sayfa sayısı kısmında da rakamlar sürekli olarak kendi doğası gereği (13 -144) arasında artarak devam etmiştir. Bu duruma ikinci satırda verilen her bir bölümün sayfa başlangıç $(13<29$ $<40<50<65<75<86<98<107<114<124<131)$ ya da bitiş numaraları $(28<39<49<64<74<85$ $<97<106<113<123<130<144$ ) örnek olarak gösterilebilir.

Bölümler ve sayfa sayısına dair verilerin belirli bir düzen içinde nasıl ilerlediğini bir çizgede göstermek olasıdır:

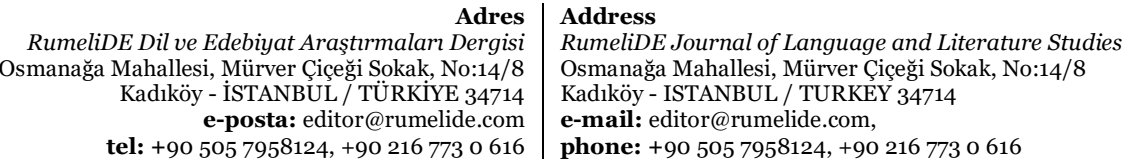

RumeliDE Dil ve Edebiyat Araşturmaları Dergisi tel: +90 $5057958124,+902167730616$ 


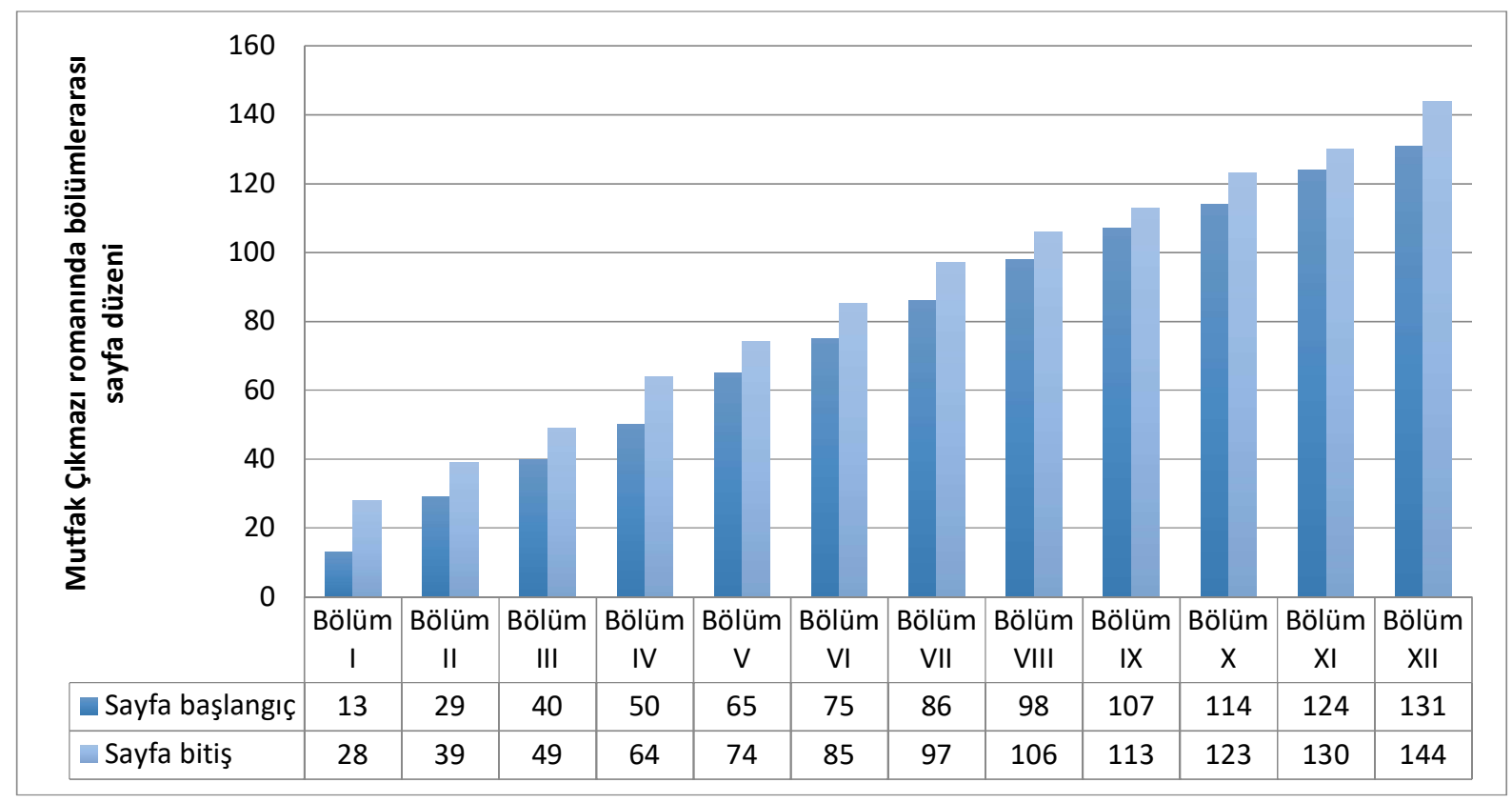

Çizge 1: A Düzenlilik durumu bölüm ve sayfaların akış durumu

Çizge 1'den de anlaşılacağı üzere Mutfak Çıkmazı romanının bölümlerarası geçiş ve sayfa yapısı zorunlu olarak kendi doğal akışı içinde ilerlemektedir. Herhangi bir bölümün sayfa sıra sayısının bozularak ani değişimlerle yer değişirmediği açıktır. Yazarın bu kısımdaki belirlemeleri keyfiyetten değil zorunluluktandır.

Ancak Tablo 1'deki (B) kısmına bakıldı̆̆ında burada bir keyfiyetten söz etmek olasıdır. Çünkü her bölüm için ayrılan sayfa miktarında bir farklılık söz konusudur. Örnek olarak yazar, romanın birinci bölümü için toplam on altı sayfa ayırmışken diğer bölümler için farklı miktarlada sayfa ayırmıştır. Bu yüzden ilgili satırdaki değerlemede her bir bölümün konumlandırıldığı sayfa miktarında en azından sayısal anlamda sistemli bir artış ya da azalışa rastlanmamıştır $(16>11>10<15>10<11<12>9>7<10>7<14)$ :

RumeliDE Dil ve Edebiyat Araşturmaları Dergisi Osmanağa Mahallesi, Mürver Çiçeği Sokak, No:14/8 Kadıköy - ISTANBUL / TÜRKIYE 34714 e-posta: editor@rumelide.com tel: +90 $5057958124,+902167730616$
Address

RumeliDE Journal of Language and Literature Studies Osmanağa Mahallesi, Mürver Çiçeği Sokak, No:14/8

Kadıköy - ISTANBUL / TURKEY 34714

e-mail: editor@rumelide.com,

phone: +90 $5057958124,+902167730616$ 


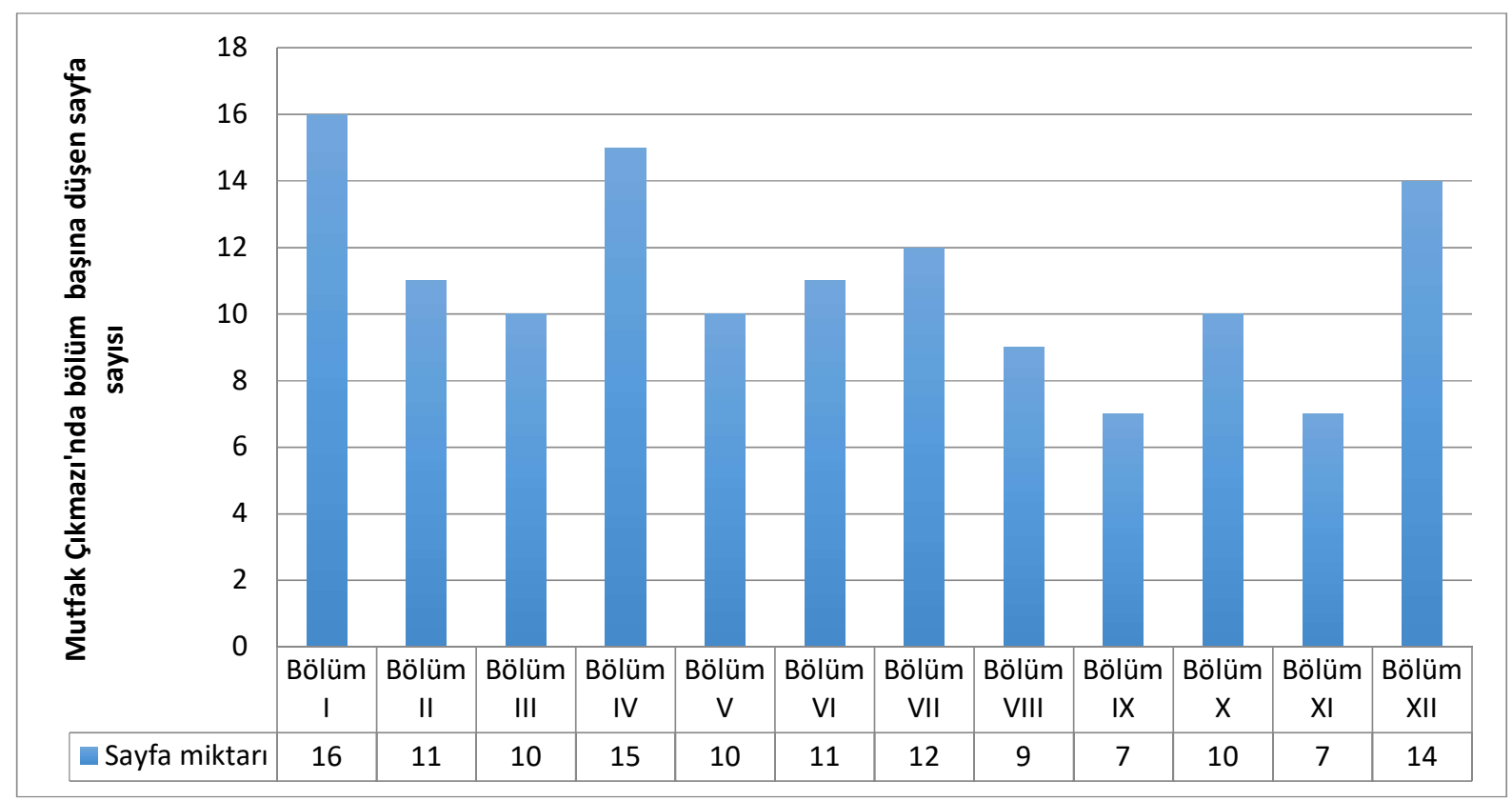

Çizge 2: B Düzensizlik durumu; bölümlerin sayfa miktarı

Çizge 2'de görüldügü üzere her bir bölüm için ayrılan sayfa miktarı değişik oranlarda azalabilmekte veya artabilmektedir. Bu durumu Tablo 2'deki düzensizlik durumu kısmında ele alınan değişim oranı ile de belirtmek mümkündür. Buna göre ilk bölüme göre ikinci bölüme ayrılan sayfa sayısının (-5) azalması, ikinci bölüme göre üçüncü bölümde ayrılan sayfa sayısının (-1), üçüncü bölüme göre dördüncü bölüme ayrılan sayfa sayısının birden (+5) artması, dördüncü bölüme göre beşinci bölüm ayrılan sayfa sayısının hızla (-5) azalması, beşinci bölüme göre altıncı bölüme ayrılan sayfa sayısının (+1) artması, altıncı bölüme göre yedinci bölüme ayrılan sayfa sayısının (+1) artması, yedinci bölüme göre sekizinci bölüme ayrllan sayfa sayısının (-3) azalması, sekizinci bölüme göre dokuzuncu bölüme ayrılan sayfa sayısının(-2) azalması, dokuzuncu bölüme göre onuncu bölüme ayrılan sayfa sayısının birden (+3) artması, onuncu bölüme göre on birinci bölüme ayrılan sayfa sayısının (-3) azalması ve on birinci bölüme göre on ikinci bölüme ayrılan sayfa sayısının birden iki katına çıkarak ( +7$)$ artması her bölüm için ayrılan sayfa sayıları arasındaki farklılığa örnektir $(-5<-1<+5>-5<+1=+1>-2<+3<-3>+7)$.

Şüphesiz ki Çizge 2'de gösterilen veriler metnin gerçekliği ile ilgili verilerdir. Buradaki düzensizlik ilişkisi yani ilgili bölümlere ayrılan sayfa miktarının kendi arasındaki iniş çıkışlar belkide anlatının iç yapısındaki ritmiyle ilgili bir durumdur. Bu bağlamda metnin gerçeklik düzlemindeki verilerin bir yerde kurgu düzlemindeki verilerle de bağlantısının olma ihtimali düșünülebilir. Böyle bir duruma anlatı zamanı ya da mekanındaki kurgusal değişimler, belirli zamanların/mekanların bölümlerarası kurgusundaki kullanım oranında benzer iniş çıkışlar, zaman ve mekan kaynaklı durumların anlatı kişileri üzerinde yarattığı durumsal etkiler; anlatı kişileri ya da temel anlatı kişisini ilgilendiren olgu ve olayların hem durumsal hem de ruhsal durumunda yarattı̆̆ı değişiklikler ve bu değişikliklerdeki iniş çıkışlı durumlar, değişim ve dönüşümler, kişilerin anlatıda belirim oranı, kişilerarası diyaloglarda söz alma miktarı, vb. farklı türden birçok örnek verilebilir.

Ayrıca Tablo 2'deki (A) ve (B) kısımlarında değerlendirilen bir başka olgu da metnin yapısal düzenlenişi içinde değerlendirilebilecek bölümlerin baş ve son sayfalarında bırakılan boşluklardır. Bölümlerarası

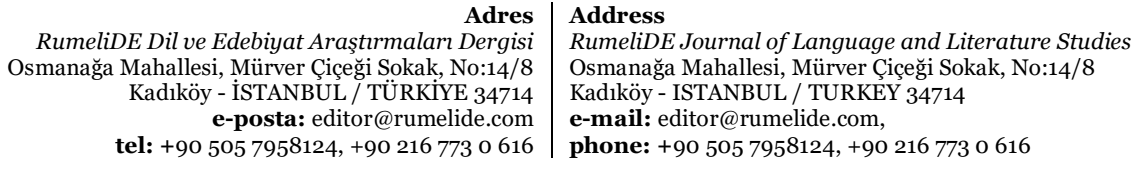


sayfalarda bırakılan boşlukların birbirine eşit olması (=), olmaması ( $\neq$ ) göstergeleri ile belirtilmiştir. Buna göre düzenlilik kısmında (11) satır olan bölüm başı sayfa boşluk oranının diğer bölümlerin başlangıç sayfalarında da eşit (=) oranda olduğu görülmüştür. Ancak aynı durumu bölüm sonu sayfa boşluk oranı için tekrar etmek mümkün görünmemektedir. Çünkü bölüm sonu sayfa boşluk oranları bölümden bölüme değişiklik göstermektedir. Bu durum ilgili tabloda da belirtildiği üzere boşluklar satır sayıları göz önünde bulundurularak büyük (>) ve küçük (<) denklemi içinde verilebilmektedir. Bölüm başı sayfa boşluk oranları (11) satır ile birbirine eşittir (I = II = III =IV = V = VI =VII = VIII =IX = X = XI = XII). Bölüm sonu sayfa boşluk oranları ise (I.) ve (II.) bölümün sonları hariç yapılandırıldıkları sıra ile birbirine eşit değildir (I = II $\neq$ III $\neq$ $\mathrm{IV} \neq \mathrm{V} \neq \mathrm{VI} \neq \mathrm{VII} \neq \mathrm{VIII} \neq \mathrm{IX} \neq \mathrm{X} \neq \mathrm{XI} \neq \mathrm{XII}$ ). Bu durumu Tablo 2'de belirtiği üzere ilgili bölümlerin sonlarında bırakılan boşluklara ait satır sayıları arasındaki farkı büyüklük $(>)$ ve küçüklük $(<)$ durumuna göre belirtmek de olasıdır (II $<$ III $>$ IV $<$ V $>$ VI $<$ VII $>$ VIII $>$ IX $<$ X $>$ XI $<$ XII ). Satır boşluk sayılarına göre elde edilen yukarıdaki verilerin bir çizge üzerinde gösterimi de olasıdır:

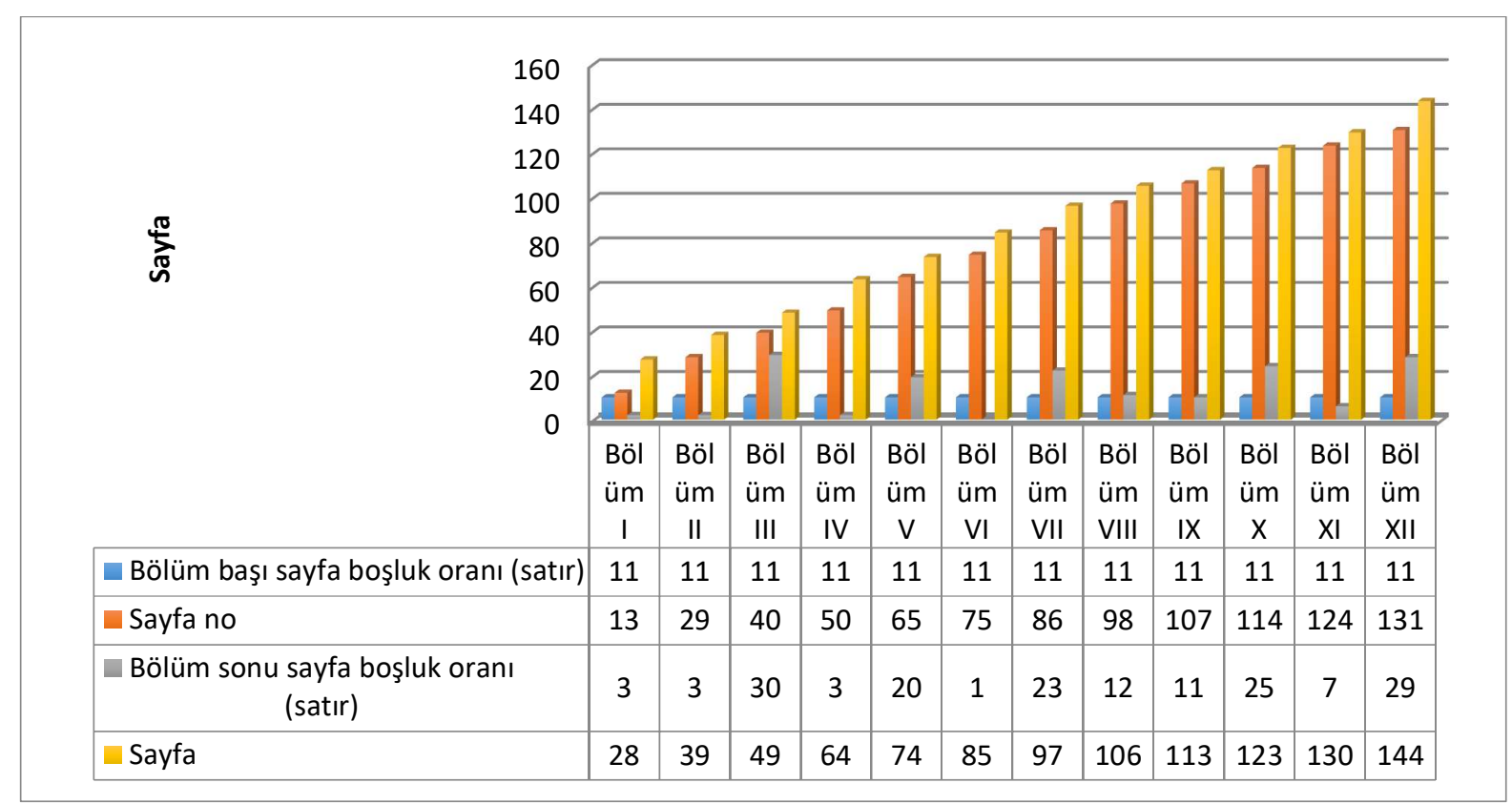

Çizge 3: Bölümlerarası boşluklarda düzenlilik/düzensizlik durumu

Tablo 2'deki verilerin Çizelge 3'deki detaylı sunumu bölüm başı satır boşluk oranı (mavi renk) ile bölüm sonu satır boşluk oranının (yeşil renk) aynı düzlemde ve belirli bir düzen içinde ilerlemediğini göstermektedir. Mutfak Çıkmazı romanında her bölümün başında bırakılan satır boşluk sayıları (11) birbirine eşit (=) iken bölüm sonunda bırakılan satır boşluk sayıları birçok bölümde değişiklik ( $\neq$ ) göstermekte ve belirli bir düzen içinde olmadığı görülmektedir.

Sayfalardaki boşluklar için satır hesabı yapılmıştır. Metnin basılı olduğu ebatda bir tam sayfanın kapasitesi baștan sona (34) satırdır. Romanın başlatıldığı sayfa (13) ile bitişine gelen sayfa (144) arasında toplam (132) sayfa bulunmaktadır. Yani Tahsin Yücel Mutfak Çıkmazı anlatısı için (132) sayfa ayırmıştır. Çizge 3'te de görüldüğü gibi bölüm başı düzenli sayfa boşluk oranı (mavi renk toplamı: 132 satır) ve bölüm sonu düzensiz sayfa boşluk oranı (yeşil renk toplamı: 167 satır) dır. Romanda satır sayısı bağlamındaki toplam boşluk oranı ise (mavi ve yeşil toplamı: 301) satırdır. Burada her sayfada için ayrılan satır sayısı (34) ile anlatı içi ayrılan sayfa sayısı (132) birbiriyle çarpıldığında $(132 * 34=4.448)$ toplam satır sayısı ortaya

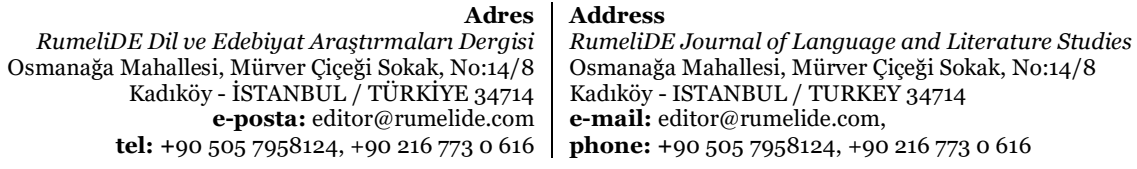


çıkmaktadır. Ancak burada Çizge 3'te belirtilen oranlarda bırakılan toplam satır sayısı (301) ile metnin (132) sayfasını kapsayan kullanılabilecek satır sayısı birbirinden çıkarıldığında da (4.448 - $301=4.187$ ) ye ulaşılmaktadır. Sonuç olarak metin içinde, anlatı için ayrılan sayfaların toplamında (132 sayfa) kullanılan satır sayısının (4187) olduğu gözlemlenmektedir. Dolayısıyla bölüm başı ve bölüm sonu sayfa boşluk oranları anlatının her bir sayfasında kullanılan ve kullanılmayan satırların toplamından elde edilmiştir.

Buraya kadar belirlenen ölçütler doğrultusunda Mutfak Çıkmazı metninin yapısal düzenlenişine bakıldığında metnin oluşmasını sağlayan ana çarkın her bir elemanı arasında hem düzenli hemde düzensiz bir iliş̧iler ağı gözlemlenmektedir.

\section{b. Sözceleme durumu}

Emile Benveniste'e göre sözcelemenin en belirleyici özelliği üçlü yapısındadır. Bu yapı, konuşan bir özneyi (ben ve ben'in varsaydı̆̆ı bir sen; dinleyici/okuyucu/alıcı vb.), bu iki eyleyenin sözceleme anında oldukları yeri (burası) ve içinde bulundukları zamanı (şu an) varsaymaktadır (Kıran ve Kıran 2013: 230). Duruma dilbilim açısından bakıldığında bu durumu dilin kullanıldığı doğal ortamlarda incelemek gerekir. Ancak göstergebilim açısından bakıldığında sözceleme kuramının göstergebilim kuramına dahil edilmesiyle elde edilen söylem göstergebilimi çerçevesinde konuşan özne, dinleyicisi, bulundukları mekan ve zaman gibi ögeleri içinde barındıran sözceleme süreçlerinin incelenmesi yazınsal yapıtlar için de geçerlidir (referans ver).

Yücel'in Mutfak Çıkmazı tamamlanmış bir anlatı yani sözcedir. Ancak bu anlatı her ne kadar sonlanmış ve kapalı bir metin olma özelliği taşısa da içinde sözceleme durumuyla ilgili özellikleri barındıran yazınsal bir söylemdir aynı zamanda. Dolayısıyla Yücel'in anlatısında sözceleme süreçlerinin oluşturucu ögelerinin izlerini sürmek mümkündür. Bu bağlamda, yukarıda Benveniste'nin de öne sürdüğü yapıdan hareketle, bir sözce olarak da değerlendirilen anlatının mutlak "bir sözceleme öznesi, sözceleme öznesinin alıcısı, sözceleme yeri ve sözceleme zamanı bulunmaktadır” (Günay, 2018: 60):

\begin{tabular}{|l|l|}
\hline Sözce & Mutfak Çıkmazı \\
\hline Sözceleme öznesi & Tahsin Yücel \\
\hline Sözceleme yeri & İstanbul \\
\hline Sözceleme zamanı & 1960 \\
\hline Sözcelemenin alıcısı & Okuyucu \\
\hline
\end{tabular}

Tablo 3: Mutfak Çıkmazı'nda sözceleme durumu I

Sözceleme durumu, sözcenin gerçekten üretildiği somut durumu belirtir. "Sözceleme durumu; sözceleme öznesi, sözceleme zamanı, sözceleme yeri ve sözcelemenin alıcısı kavramlarını içermektedir" (Günay, 2018, p. 57). Çözümlemenin ilk bölümünde metnin yapısal düzenlenişine yönelik elde edilen bulguların devamı niteliğinde sayllan Tablo 3'deki bölümleme yine ilgili metnin bir sözce olarak oluşumunda rol oynayan bileşenleri ve sözceleme durumunu göstermektedir. Bu tabloda sözce olarak ele alınan inceleme nesnesinin belirli bir kişi tarafından (sözceleme öznesi Tahsin Yücel), belirli bir yerde (İstanbul), belirli bir zaman dilimde (1960), belirli bir kitleye (okuyucu) hitaben yazılmış olduğu belirtilmektedir. Dolayısıyla metnin kim tarafından, nerede, ne zaman ve kimin için yazıldığı sorularının cevabı metnin üretim sürecinin durumu, başka bir deyişle sözceleme durumunu ortaya koymaktadır (Kalelioğlu, 2020: 101).

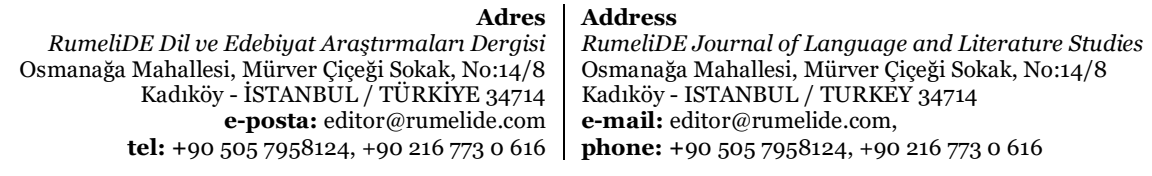


Örnek olarak sözceleme öznesi Tahsin Yücel'in sözcelemenin alıcısı okurları için romanının başında belirttiği düşüncelerini "Sunuş Yerine" başlıklı yazısında görmek olasıdır. Bu yazı aracılığıyla sözceleme öznesi, sözcelemenin alıcısı ile bir etkileșime girmektedir. "Bir zamanlar coşkuyla yazdığınız, son noktasını koyarken de tam tasarladığınız gibi olduğundan kuşku duymadığınız bir kitabı, diyelim ki bir romanı, uzun yıllardan sonra yeniden açıp da kendinize uzak, hatta nerdeyse yabancı bulursanız, bu izlenimi neyle açıklarsınız?" diyerek başlayan "[...] Bana kalırsa, tüm bunların belli bir payı olabilir sözünü ettiğimiz izlenimde. [...]Ne olursa olsun, ilk benimsediğimiz yaklaşımın en doğru yaklaşım olduğuna inanmamışsak, belirli bir öğretiye bağnazca bağlanmamışsak, yalnızca bilmek için bile olsa, başka yapıtlara, başka anlayışlara kapımızı sımsıkı kapatmamışsak, her alanda olduğu gibi yazın alanında da geliştiririz kendimizi" (2020: 9-10) diye devam eden ve "yaklaşımını benimseyelim benimsemeyelim, yapıtını beğenelim beğenmeyelim, Balzac'ı okumadan önceki romancı kişiliğimizle Balzac'ı okuduktan sonraki romancı kişiliğimiz arasında küçük de olsa bir ayrım vardır ister istemez. Kısacası, okuduklarımız sürekli bir şeyler kazandırır bize. Ama yazdıklarımız da öyle" (2020: 10-11) diyerek bir süre sonra sözlerini sözcelemenin alıcısını düşünmeye iten "[...] yaptıklarımız da bizim değişik yönlerimiz, değişik yüzlerimiz değil midir?” (2020: 11) bir soruyla noktalar.

Burada koyu renkle belirtilmiş sözcükler sözceleme öznesinin varlığını kanıtlayan sözcükler olarak değerlendirilebilir. Söz konusu alıntılar sözce değeri taşımaktadır. Çünkü hepsi "somuttur ve bir sözceleme durumu içinde gerçek bir kişi (sözceleme öznesi) tarafından yazılmıştır" (Kıran ve Kıran, 2011: 125). Sözceleme öznesi Yücel'in alıntılanan son sözcesi Benveniste'in önerdiği yapı içinde değerlendirildiğinde; sözceleme öznesi olarak ben (kişi) sözceleme zamanında şimdi (zaman belirteci) sözceleme yerinde burada (uzam belirteci) sözcelemenin alıcısı olarak size soruyorum: Yaptıklarımız da bizim değişik yönlerimiz, değişik yüzlerimiz değil midir? şeklinde ilişkilendirilebilir. Gerek sözceleme öznesi ve varsayılan alıcısı gerekse sözcelemenin yeri ve zamanı birer söylemsel ögeden ibarettir. Buradaki her bir ögenin değerini sözceleme durumu ve bağlam belirlemektedir.

Sözceleme ve sözce arasındaki ayrımı yapmak önemlidir. Sözceleme başlı başına üretime dayalı bir eylem, bu eylem neticesinde ortaya çıkan sözce, sözcenin ortaya çıamasında geçen zaman ise üretim sürecidir. Sözceleme öznesinin eyleminin somut ve gözlemlenebilir sonucu olan "sözce zaman zaman tek bir sözcük, bir tümce, bir paragraf ya da hacimli bir roman olarak karşımıza çıkmaktadır. Sözce, sözceleme öznesinin iletişim ortamında belirli bir amaçla ürettiği bütünlüğü olan dilsel bir yapıdır. Bu bağlamda kimi zaman romandaki bir tümce kimi zaman da romanın tamamı sözce olarak ele alınabilecek niteliktedir" (Günay, 2018: 66). Bu bağlamda bir sözce olan Yücel'in Mutfak Çıkmazı romanının kapağını açarak kurgunun içinde de sözceleme durumuna dair bazı belirlemeler yapmak olasıdır.

Romanın sözceleme durumunun betimlenmesi kuramsal açıdan anlatıcının ve anlatılanın konumunu belirler. Bu noktada anlatıbilimde de yer alan metin, anlatı ve öykü kavramlarını incelemeye dahil ederek Mutfak Çıkmazı romanını sözceleme durumu açısından geniş bir bakış açısıyla irdelemek mümkündür. Böyle bir inceleme "gerçeklik düzlemi ve kurgusal düzlem olmak üzere iki farklı grupta detaylandırılabilir" (Kalelioğlu, 2020: 101). Metnin iki kapağı dışında kalan sözceleme öznesi, sözce, sözcelenen özne gibi ögeleri gerçeklik düzlemiyle, metnin iki kapağı içinde kalan sözcelenmiş sözce öznesi, anlatı, sözcelenmiş sözcenin alıcısı, sözce öznesi ve öykü gibi ögeleri ise kurgusal düzlemle anmak gerekir. Buna göre sözceleme durumu bağlamında anlatıcının ve anlatılanın durumunu (konumunu) yansıtan oluşturucu ögeleri özelliklerine göre birbirinden ayırmak mümkündür:

\begin{tabular}{|l|l|l|l|l|}
\hline $\begin{array}{l}\text { Gerçeklik } \\
\text { düzlemi }\end{array}$ & $\begin{array}{l}\text { Metindışı } \\
\text { ögeler }\end{array}$ & $\begin{array}{l}\text { Sözceleme öznesi (Tahsin } \\
\text { Yücel) }\end{array}$ & Metin & Sözcelenen özne (okuyucu) \\
\hline
\end{tabular}

Adres | Address

RumeliDE Dil ve Edebiyat Araştırmalar Dergisi $\quad$ RumeliDE Journal of Language and Literature Studies Osmanağa Mahallesi, Mürver Çiçeği Sokak, No:14/8 $\quad$ Osmanağa Mahallesi, Mürver Çiçeği Sokak, No:14/8 Kadıköy - ÍSTANBUL / TÜRKIYE 34714 Kadıköy - ISTANBUL / TURKEY 34714 e-posta: editor@rumelide.com e-mail: editor@rumelide.com, tel: +90 505 7958124, +90 2167730616 phone: +90 505 7958124, +90 2167730616 


\begin{tabular}{|l|l|l|l|l|}
\hline & & & $\begin{array}{l}\text { (Mutfak } \\
\text { Çıkmazı) }\end{array}$ & \\
\hline \multirow{2}{*}{$\begin{array}{l}\text { Kurgusal } \\
\text { düzlem }\end{array}$} & $\begin{array}{l}\text { Metiniçi } \\
\text { ögeler }\end{array}$ & $\begin{array}{l}\text { Sözcelenmiş sözce öznesi } \\
\text { (anlatıcı=gönderen) }\end{array}$ & $\begin{array}{l}\text { Anlatı } \\
\text { (anlatma } \\
\text { öykü) }\end{array}$ & $\begin{array}{l}\text { Sözcelenmiş sözcenin alıcısı } \\
\text { (anlatılan=gönderilen) }\end{array}$ \\
\cline { 3 - 5 } & & $\begin{array}{l}\text { Sözce öznesi konuşan/eyleyen } \\
\text { (anlatı kişisi=karakter) }\end{array}$ & $\begin{array}{l}\text { Öykü } \\
\text { (karakter + } \\
\text { eylem) }\end{array}$ & $\begin{array}{l}\text { Sözce öznesi dinleyen/eyleyen } \\
\text { (anlatı kişisi=karakter) }\end{array}$ \\
\hline
\end{tabular}

Tablo 4: Mutfak Çıkmazı́nda anlatıcının ve anlatılanın konumu (Kalelioğlu'ndan uyarlanmıştır, 2020: 102)

Tablo 4'de belirtilen kavramlar ve aralarındaki ilişki iki farklı düzlemde gösterilmiştir.

“Gerçeklik düzlemi, sözcelenmiş metnin iki kapağı dışındaki dünyayla ilgilidir. Bu evrende kurgu yoktur, ancak kurgulayan sözceleme öznesi vardır. Bu evrende öykü ya da anlatma da yoktur, sözcelenmiş metin vardır. Gerçeklik düzleminin sözceleme öznesinin edimiyle oluşturduğu metnin hedefinde ise sözcelenen özne olarak okur vardır. Kurgusal düzlemde ise herşey sözceleme öznesinin sözcelediği metnin iki kapağı arasında kalan kısımla ilgilidir. Bu düzlemde sözcelenmiş sözce öznesi olarak "anlatının sesi" belirmektedir. Gerçeklik düzlemindeki sözceleme öznesi (yazar), sözcesinde (metin) kurguladığı herşeyi kurgusal düzlemdeki anlatısında sözcelenmiş sözce öznesi (anlatıcı) kanalıyla sözcelenmiş sözcenin alıcısına (anlatılan) aktarmaktadır" (Kalelioğlu, 2020: 102).

Metnin gerçeklik düzlemini anlamlı kılan ögeler:

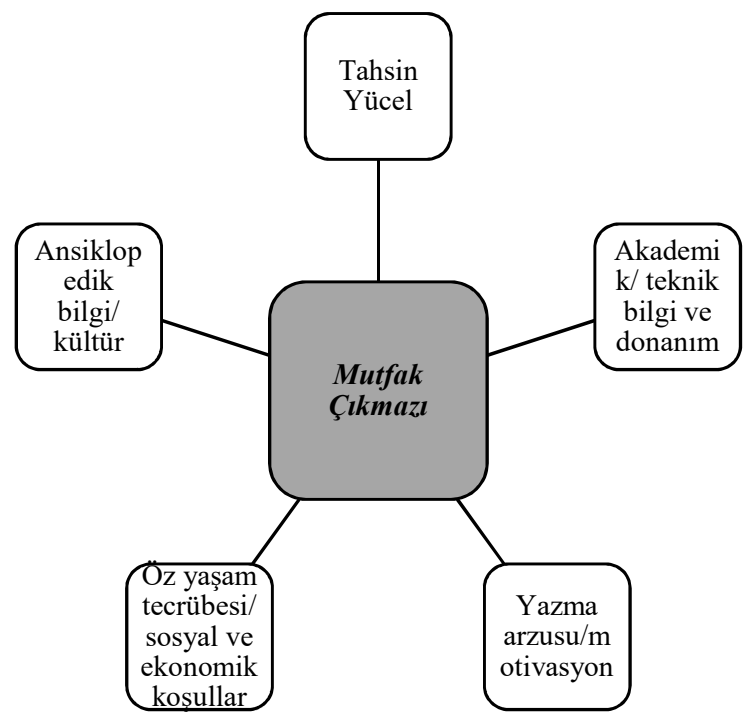

Çizge 4: Gerçeklik düzlemine değer katan ögeler

Romanın kurgusu dışında kalan gerçek dünya, yazarın öz yaşamındaki olumlu/olumsuz tecrübelerini, genel kültürünü, akademik bilgi ve donanımını, ve yazma noktasındaki istekliliğini kapsamaktadır. Bu yüzden değil midir Yücel'in gerçek yaşamında tecrübe ettiği okuma yolculuğunda Dostyevski, Rimbaurd, Orhan Kemal, Balzac, Valéry, ve Sokrates gibi isimleri ve bazı yapıtlarını öne çıarması ve bunların kendi üzerindeki etkilerini sorgulama yoluyla 'Sunuş Yerine' olan kısımda okuyucusuyla paylaşması? "Tahsin Yücel romanın girişinde, yazın alanıyla ilgili aynayı kendine tutmuştur. [...] Bunları, kendi yazın sürecinin

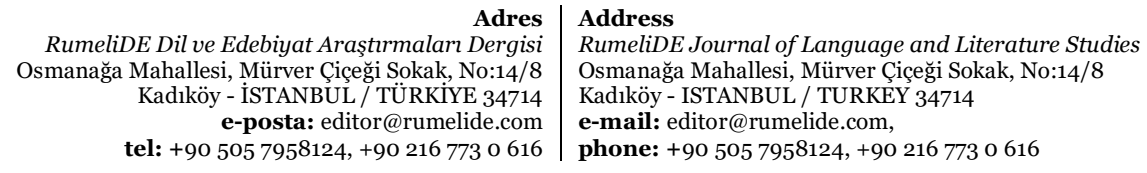


gelişimi konusunda okuru bilgilendirmek için yaptığını düşündüm ben" (Kaygusuz Şimşek, 2018)2 ${ }^{2}$. Çizge 4'deki verilerden yola çıkarak gerçeklik düzlemindeki sözceleme öznesinin sözcesini üretebilmesindeki önemli bazı etkenleri görmek mümkündür. Bunların eksikliği demek bugün Mutfak Çıkmazı gibi bir romanın Türk edebiyatında varlık gösterememesi demek olurdu.

Tablo 4'de verilen kurgusal düzlemde ise metiniçi ögeler iki farklı boyutta gösterilmiştir. Bunlardan ilki, gerçek dünyada yer alan sözceleme öznesinin, kurgusal düzlemde yarattığı sözcüsü yani anlatıcısıdır. Bu düzlemde metnin anlatısallık özelliği ile birlikte sözcelenmiş sözce öznesi olan anlatıcının metne kattığı ses yani anlatının sesi dikkat çekmektedir. Burada da bir ilişkiler ağı söz konusudur:

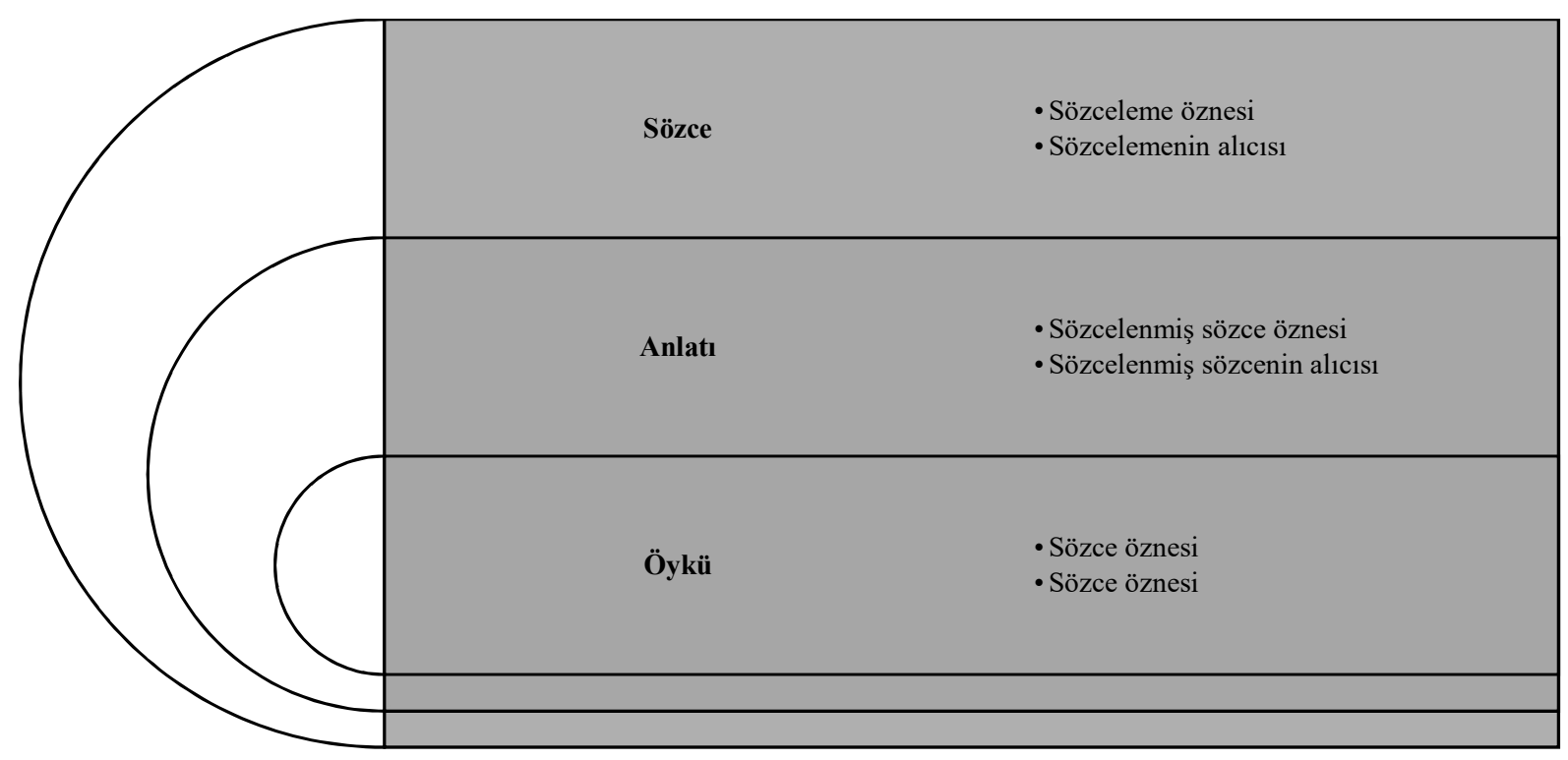

Çizge 5: Mutfak Çıkmazı'nda düzlemler, ögeler ve ilişkiler

Göstergebilimde herhangi bir şeyin yerini belirlerken ikili karşıtlıklardan yararlanmak olasıdır. Bu durum belirli bir düzlemde yer alan olguların karşılaştırılması sırasında her bir eksenin belirleyici özelliklerini daha iyi bir şekilde ortaya çıkarmak açısından önemlidir. Bu sebeple Çizge 5, kapsayan/kapsanan karşıtlığı içinde yorumlanabilir. Sonlanmış bir metin olan Mutfak Çıkmazı bir sözce, bu sözcenin oluşturucu katmanları ise anlatı ve öykü katmanlarıdır (sözce > anlatı > öykü). Her üç katmanın aktif eyleyenleri ve bu eyleyenlerin üstlendikleri farklı görevleri bulunmaktadır. Sözce düzleminde sözceleme öznesi kurgusunda yarattığı sözcüsü vasıtasıyla anlatı düzlemini harekete geçirir. Sözceleme öznesinin muhatabı gerçek okur iken (Tahsin Yücel (gönderen)) $\rightarrow$ okur (gönderilen)), anlatı düzleminde sözcelenmiş sözce öznesinin muhatabı sözcelenmiş sözcenin alıcısı (anlatan (gönderen)) $\rightarrow$ anlatılan (gönderilen)), öykü düzleminde ise sözce öznesi bir başka sözce öznesinin (konuşan ve eyleyen anlatı kişisi (gönderen)) $\rightarrow$ dinleyen ve eyleyen anlatı kişisi (gönderilen)) muhatabıdır. Fakat "her ne kadar anlatıcı anlatıyı anlatılana anlatsa da bunun asıl alıcısı gerçek dünyadaki okuyucudur” (Günay, 2018: 111).

Gerek gerçeklik düzleminde yer alan sözcenin oluşturucu ögeleri gerekse kurgu düzleminde yer alan anlatı ve öykünün oluşturucu ögeleri olsun bunların hepsi kapsayan/kapsanan karşıtllğı içinde gönderen ve

2 Gazete Öneri

Adres
RumeliDE Dil ve Edebiyat Araşturmaları Dergisi Osmanağa Mahallesi, Mürver Çiçeği Sokak, No:14/8 Kadıköy - ISTANBUL / TÜRKIYE 34714 e-posta: editor@rumelide.com tel: +90 $5057958124,+902167730616$
Address

RumeliDE Journal of Language and Literature Studies

Osmanağa Mahallesi, Mürver Çiçeği Sokak, No:14/8

Kadıköy - ISTANBUL / TURKEY 34714

e-mail: editor@rumelide.com,

phone: +90 $5057958124,+902167730616$ 
gönderilen açısından (sözceleme öznesi > sözcelenmiş sözce öznesi > sözce öznesi), (sözcelemenin alıcısı > sözcelenmiş sözcenin alıcısı > sözce öznesi) şeklinde sınıflandırmak mümkündür.

Ancak gerçek kişi ve kağıttan kişilere yönelik bir ayrımın da olduğunu unutmamak gerekir. Gerçeklik düzleminde yer alan sözceleme öznesi ile sözcelemenin alıcısı "gerçek kişiler" (Chatman, 1978: 151) iken; kurgu düzleminde her iki katmanda da yer alan diğer kişiler kağıttan kişilerdir. Bu kişileri "gerçek kişiler ve ima edilen kişiler" (Chatman, 1978: 151) olarak tanımlamak da mümkündür. Dolayısıyla kurgusal düzlemde beliren anlatıcı (sözcelenmiş sözce öznesi), anlatısını doğrudan gerçek okuyucuya değil, metnin içinde olduğu varsayılan ya da" ima edilen okuyucuya" (1978: 151) yani sözcelenmiş sözcenin alıcısına anlatmaktadır. Burada bir anlatısallık ve bu anlatısallık içinde bir iletişim durumu söz konusudur:

\begin{tabular}{|l|l|l|}
\hline Gerçeklik düzlemi & Kurgusal düzlem & Gerçeklik düzlemi \\
\hline $\begin{array}{l}\text { Gerçek yazar } \rightarrow \\
\downarrow\end{array}$ & $\begin{array}{l}\text { Ben anlatıcı } \rightarrow(\text { Anlatıcı }) \rightarrow(\text { Muhatap }) \rightarrow \text { İma edilen okur } \\
\downarrow\end{array}$ & $\rightarrow$ Gerçek okur \\
\hline Gerçek kişi & Kurmaca kişiler & Gerçek kişi \\
\hline
\end{tabular}

Tablo 5: Düzlemlerarası iletişim döngüsü (Chatman'dan uyarlanmıştır, 1978: 151).

Anlatıbilimin verileri kapsamında sözcelenmiş sözce öznesi anlatıcının konumunu belirlemede tümbilimci, içsel ve dışsal olarak üç temel bakış açısı vardır. Tablo 5'de gerçeklik düzleminden kurgusal düzleme ve sonrasında da kurgusal düzlemden gerçeklik düzlemine sıralı bir geçiş söz konusudur. Burada sözceleme öznesi Yücel, sözcesi olan Mutfak Çıkmazı'nda kurguladığı anlam evrenindeki iletişim döngüsünü oluşturup okuyucuya sunmuştur. Bu iletişim döngüsü içinde iki farklı anlatıcıya rastlanmaktadır. Bunlardan ilki birinci tekil şahıs adılının (ben) kullanıldığı anlatı kişisidir:

\begin{abstract}
"Ne yapsalar, ne deseler şaşılmaz. Çok büyük bir yitik yitikleri. Yitik bile değil belki, bir yıkım, bir toplu ölüm, belki daha da beteri. Evlerine bir dakika girip çıkmak yeter bunu anlamak için, kapının önünden geçmek de yeter. Çökmüş yüzlerini gördüm, bükülmüş bellerini gördüm, ezik seslerini duydum, deliye döndüm. Ölü evleri hiç böyle olmazdı bizim oralarda, hem de hepsi birbirine benzerdi” (Yücel, 2020: 13).
\end{abstract}

Diğer anlatıcı ise kurgusal düzlemin öykü katmanında yer alan sözce öznelerinin (konuşan, dinleyen, eyleyen anlatı kişileri) ne yaptıklarını ve yapacaklarını fazlasıyla bilen, duyan ve anlayan tümbilici ya da başka bir deyişle tanrı bakış açısına sahip bir anlatıcıdır:

\begin{abstract}
“Bir başka odada erkekler vardı. Odanın kapısı sürgülenmişti. Kimselere açılmıyordu. Öyle ya, erkekler ağlamazlardı o yerlerde, o yerlerde erkeklerin ağlaması ayıptı. Onlarsa kadınlar gibi ağlıyorlardı. Daha korkunç, daha derin ağlıyorlardı, bunun için kapalıydı kapıları. Başka ölü evlerinde erkekler kederle savaşırlardı. Ölünün karanlık gölgesini silmek isterlerdi gözlerinden. Bir susarlar, bir konuşurlar, konudan konuya geçerlerdi. Toprağın üstünde kalırdı sözleri, bağdan, bahçeden, işlerden, büyüyen çocuklardan söz ederlerdi. Çocuklardan söz edilirken gülümseyenler olurdu. Ama onlar ağlıyorlardı" (Yücel, 2020: 14).
\end{abstract}

Sözceleme öznesinin anlatının ilk paragrafında yer verdiği anlatıcı ile sonrasında yer verdiği anlatıcı arasında açık bir fark gözlemlenmektedir. Giriş paragrafında içsel bir bakış açısı varken (gördüm, duydum, döndüm, bizim oralarda), örnek alıntılardan anlaşılacağı gibi anlatının devamında tümbilici bir bakış açısı bulunmaktadır (vardı, sürgülenmişti, ağlıyorlardı, kapalıydı vb.). Burada anlatıcıdan anlatıcıya bir dönüşüm söz konusudur (içsel bakış açlı anlatıcı $\rightarrow$ tümbilici bakış açılı anlatıcı) ya dönüşmüştür. Alıntılardaki koyu sözcüklerden yola çıkarak sözceleme öznesinin kurgusunda yarattığ 1 bu geçici durum gerçek okuyucu üzerindeki etkiyi arttırma ve okuyucuyu anlatının içine çekme amaçlı kurgulanmış olabilir. İçsel bakış açısına sahip bir anlatı kişisiyle başlayan roman ilk paragraftan sonra her şeyi bilen bir tümbilici anlatı

\footnotetext{
Adres
RumeliDE Dil ve Edebiyat Araşturmaları Dergisi Osmanağa Mahallesi, Mürver Çiçeği Sokak, No:14/8 Kadıköy - ISTANBUL / TÜRKIYE 34714 e-posta: editor@rumelide.com tel: +90 $5057958124,+902167730616$

Address

RumeliDE Journal of Language and Literature Studies

Osmanağa Mahallesi, Mürver Çiçeği Sokak, No:14/8

Kadıköy - ISTANBUL / TURKEY 34714

e-mail: editor@rumelide.com,

phone: +90 505 7958124, +90 2167730616
} 
kişisine dönüşmektedir. Sebebi ne olursa olsun burada bir anlatının farklı bakış açılarıyla farklı anlatı kişileri tarafından anlatılabileceği sonucu ortaya çıkmaktadır.

Çizge 5'e dönülecek olursa anlatıdan sonra öykü kısmı gelmektedir. Anlatıda gerçek kimliğini hatta adı dahi bilinmeyen bir anlatıcı varken öyküde ismi, ne iş yaptığı, nerede yaşadığı, nelerden hoşlanıp hoşlanmadığı gibi belirli özelliklere sahip ikincil türden kurmaca kişiler (sözce özneleri) vardır. Öykü düzleminde yer verilen bu kişiler için detaylı belirleme yapmak olasıdır. Bu belirlemede anlatı düzleminde yer alan sözcelenmiş sözce öznesinin anlatısını sözcelenmiş sözcenin alıcısına aktarırken zaman zaman sözü sözce öznelerine verdiği görülür ve burada da Tablo 5 'de sunulan iletişim döngüsünün bir benzeri görülür:

"O da çok geçmeden geldi. Gelir gelmez boynuna atıldı. Ama İlyas tiril tiril titriyordu, çabucak sıyrıldı. Oturdu, ona da bir yer gösterdi. Bir-iki kez öksürdü, gözlerini yere dikti, ne zamandır söylemeye çalışıp da bir türlü söyleyemediği, kucaklaşmalar içinde yersiz bulduğu sözü bir çırpıda söyleyiverdi.

"Seni seviyorum," dedi kitaplardaki gibi. Kıpkırmızı kesildi, yutkundu.

"Deli gibi," diye ekledi.

Emel güldü. Sonra yüzü birdenbire değiști.

"Sahi mi?" diye sordu. Sanki bilmiyordu!

“Evet, sahi, elbette sahi, hiç yalan olur mu?” dedi Divitoğlu (Yücel, 2020: 18-19).

Alıntıda sözcelenmiş sözce öznesi (tümbilici anlatıcı) sözcelenmiş sözcenin alıcısına (ima edilen okuyucu) sözcesini (geldi, atıldı, titriyordu, oturdu, gösterdi, öksürdü, söyleyiverdi, dedi, yutkundu, ekledi, değişti, bilmiyordu) gibi sözcüklerle aktarmaktadır. Sözcelenmiş sözce öznesi sözcesini bitirdikten sonra sözü sözce öznesine vermektedir. Yukarıda Yücel'in anlatısındaki sözceleme öznelerinden Divitoğlu ve Emel arasında geçen diyalog bu duruma örnektir. İletişim döngüsü çerçevesinde burada da sözceleme öznelerinin konuşan ve dinleyen olarak dönüşümlü iki farklı görevi söz konusudur:

Anlatıcı (bir çırpıda söyleyiverdi) $\rightarrow$ Divitoğlu (seni seviyorum) $\rightarrow$ anlatıcı (dedi) $\rightarrow$ Emel (sahi mi) $\rightarrow$ anlatıcı (diye sordu) $\rightarrow$ Divitoğlu (evet sahi) $\rightarrow$ anlatıcı (dedi) $\rightarrow$ Emel.

Burada kurgusal düzlemin iki katmanında yer alan iletişim döngüsü öykü düzleminde sözce özneleri Divitoğlu ve Emel arasında, anlatı düzleminde ise sözcelenmiş sözce öznesi ve sözcelenmiş sözcenin alıcısı olan kurmaca okur arasında geçmektedir. Öykü düzleminde her iki sözceleme öznesinin birbiriyle konuşmak ve birbirini dinlemek gibi bir görevi bulunmaktadır. Anlatı düzleminde ise sözcelenmiş sözce öznesi bir yandan bulunduğu anlatı düzlemindeki okuru için bir aktaran, diğer yandan da öykü düzleminde yer alan sözce özneleri için de konuşucu/dinleyici bağlamında görev dağılımı yapan kişidir. Öykü düzleminde değişik sözceleme özneleriyle karşlaş̧mak mümkündür. Bu durum romanın diğer katmanlarının da yer aldığı bir çizgede gösterilebilir:

RumeliDE Dil ve Edebiyat Araştırmaları Dergisi Osmanağa Mahallesi, Mürver Çiçeği Sokak, No:14/8 Kadıköy - ISTANBUL / TÜRKIYE 34714 e-posta: editor@rumelide.com tel: +90 505 7958124, +90 2167730616
Address

RumeliDE Journal of Language and Literature Studies

Osmanağa Mahallesi, Mürver Çiçeği Sokak, No:14/8

Kadıköy - ISTANBUL / TURKEY 34714

e-mail: editor@rumelide.com,

phone: +90 505 7958124, +90 2167730616 


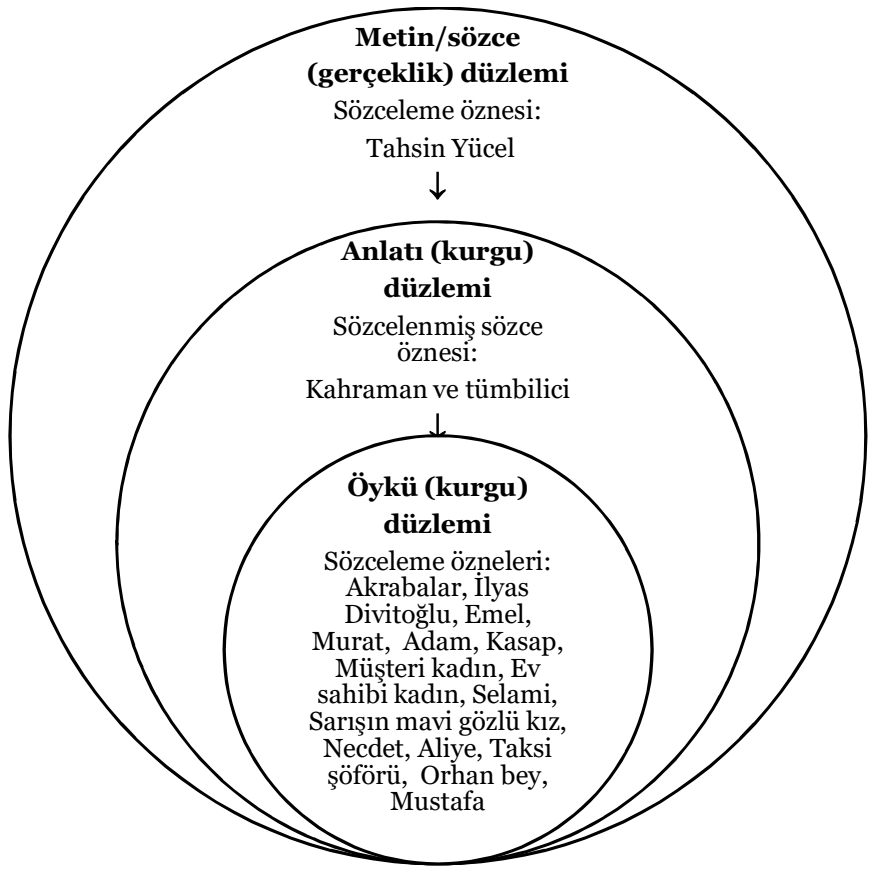

Çizge 6: Mutfak Çıkmazı'nda sözceleme durumu II

Çizge 6'da sözceleme durumuna yönelik detaylar Tablo 3'ün devamı niteliğindedir. Burada hem gerçeklik hem de kurgu düzleminin sözceleme durumu görülmektedir. Yukarıda metin, anlatı ve öykü düzlemleriyle ilgili bazı örnekler verilmiştir. Anlatı düzleminde olduğu gibi öykü düzlemi için de değiş̧ik bakış açılarıyla örnekler arttırılabilir. Mesela konuşmacı rolü üstlenmiş sözce öznelerinin sözcelerinin sıklığı karşılaştırılabilir. Böyle bir karşılaştırmada anlatı düzleminde yer alan sözcelenmiş sözce öznesinin hangi sözce öznesine, ne sıklıkta söz verdiği ortaya çıkacaktır. Bu konudaki inceleme sonraki bölümde detaylandırılacaktır.

\section{c. Sözce öznesinin iletişimdeki yeri}

Buradaki temel hareket noktası metin düzleminde yer alan sözceleme öznesinin antalı düzleminde kurguladığı sözcelenmiş sözce öznesi aracılı̆̆ıyla öykü düzlemindeki sözce öznelerine bıraktığı sözü gösteren tırnak (“...”) içindeki diyalog ve iç monologlardır:

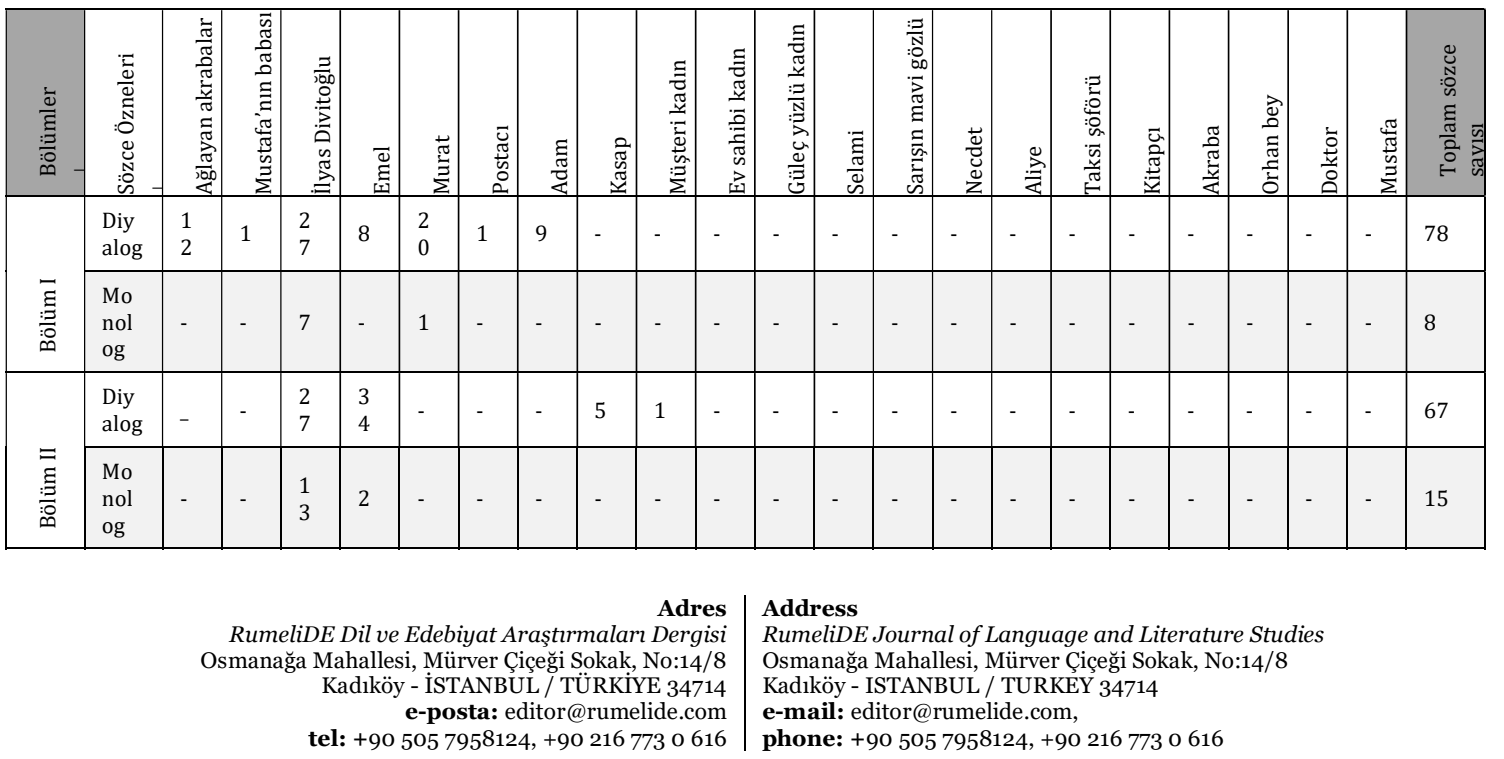




\begin{tabular}{|c|c|c|c|c|c|c|c|c|c|c|c|c|c|c|c|c|c|c|c|c|c|c|c|}
\hline \multirow[b]{2}{*}{ 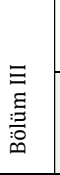 } & $\begin{array}{l}\text { Diy } \\
\text { alog }\end{array}$ & - & - & $\begin{array}{l}2 \\
1\end{array}$ & - & - & - & - & - & - & 9 & 6 & - & - & - & - & - & - & - & - & - & - & 36 \\
\hline & $\begin{array}{l}\text { Mo } \\
\text { nol } \\
\text { og }\end{array}$ & - & - & $\begin{array}{l}2 \\
8\end{array}$ & - & - & - & - & - & - & 5 & - & - & - & - & - & - & - & - & - & - & - & 33 \\
\hline \multirow[b]{2}{*}{$\begin{array}{l}\geq \\
\vdots \\
\vdots \\
\vdots \\
0\end{array}$} & $\begin{array}{l}\text { Diy } \\
\text { alog }\end{array}$ & - & - & $\begin{array}{l}4 \\
4\end{array}$ & - & $\begin{array}{l}3 \\
9\end{array}$ & - & - & - & - & - & - & $\begin{array}{l}3 \\
6\end{array}$ & - & - & - & - & - & - & - & - & - & 119 \\
\hline & $\begin{array}{l}\text { Mo } \\
\text { nol } \\
\text { og }\end{array}$ & - & - & 5 & & 1 & - & - & - & & - & - & 2 & - & - & - & - & - & - & - & - & - & 8 \\
\hline \multirow[b]{2}{*}{ 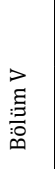 } & $\begin{array}{l}\text { Diy } \\
\text { alog }\end{array}$ & - & - & $\begin{array}{l}3 \\
3\end{array}$ & $\begin{array}{l}1 \\
4\end{array}$ & 7 & - & - & - & - & - & - & - & 9 & - & - & - & - & - & - & - & - & 63 \\
\hline & $\begin{array}{l}\text { Mo } \\
\text { nol } \\
\text { og }\end{array}$ & - & - & 4 & - & - & - & - & - & - & - & - & - & 4 & - & - & - & - & - & - & - & - & 8 \\
\hline \multirow[b]{2}{*}{$\begin{array}{l}\text { \ } \\
\vdots \\
\vdots \\
\vdots\end{array}$} & $\begin{array}{l}\text { Diy } \\
\text { alog }\end{array}$ & - & - & $\begin{array}{l}4 \\
1\end{array}$ & - & $\begin{array}{l}3 \\
6\end{array}$ & - & - & - & - & - & - & $\begin{array}{l}2 \\
9\end{array}$ & - & - & - & - & - & - & - & - & - & 106 \\
\hline & $\begin{array}{l}\text { Mo } \\
\text { nol } \\
\text { og }\end{array}$ & - & - & 8 & - & - & - & - & - & - & - & - & - & - & - & - & - & - & - & - & - & - & 8 \\
\hline \multirow[b]{2}{*}{ 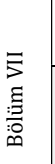 } & $\begin{array}{l}\text { Diy } \\
\text { alog }\end{array}$ & - & - & $\begin{array}{l}4 \\
7\end{array}$ & - & - & - & - & - & - & $\begin{array}{l}1 \\
2\end{array}$ & - & $\begin{array}{l}1 \\
0\end{array}$ & - & 5 & - & 2 & $\begin{array}{l}1 \\
5\end{array}$ & - & - & - & - & 91 \\
\hline & $\begin{array}{l}\text { Mo } \\
\text { nol } \\
\text { og }\end{array}$ & - & - & $\begin{array}{l}1 \\
4\end{array}$ & - & - & - & - & - & - & - & - & - & - & - & - & - & - & - & - & - & - & 14 \\
\hline \multirow{2}{*}{ 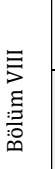 } & $\begin{array}{l}\text { Diy } \\
\text { alog }\end{array}$ & - & - & $\begin{array}{l}2 \\
7\end{array}$ & - & - & - & - & - & - & - & - & $\begin{array}{l}1 \\
0\end{array}$ & - & - & - & - & - & $\begin{array}{l}3 \\
1\end{array}$ & - & - & - & 68 \\
\hline & $\begin{array}{l}\text { Mo } \\
\text { nol } \\
\text { og }\end{array}$ & - & - & $\begin{array}{l}1 \\
2\end{array}$ & - & - & - & - & - & - & - & - & - & - & - & - & - & - & - & - & - & - & 12 \\
\hline \multirow[b]{2}{*}{ 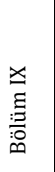 } & $\begin{array}{l}\text { Diy } \\
\text { alog }\end{array}$ & - & - & $\begin{array}{l}1 \\
8\end{array}$ & $\begin{array}{l}1 \\
0\end{array}$ & $\begin{array}{l}3 \\
9\end{array}$ & - & - & - & - & 3 & - & - & - & - & - & - & - & - & - & - & - & 70 \\
\hline & $\begin{array}{l}\text { Mo } \\
\text { nol } \\
\text { og }\end{array}$ & - & - & - & - & - & - & - & - & - & - & - & - & - & - & - & - & - & - & - & - & - & 0 \\
\hline \multirow[b]{2}{*}{ 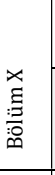 } & $\begin{array}{l}\text { Diy } \\
\text { alog }\end{array}$ & - & & $\begin{array}{l}2 \\
8\end{array}$ & $\begin{array}{l}5 \\
2\end{array}$ & $\begin{array}{l}1 \\
0\end{array}$ & - & - & - & - & - & - & - & - & - & - & - & - & - & - & - & - & 90 \\
\hline & $\begin{array}{l}\text { Mo } \\
\text { nol } \\
\text { og }\end{array}$ & - & - & 5 & 6 & - & - & - & - & - & - & - & - & - & - & - & - & - & - & - & - & - & 11 \\
\hline \multirow[b]{2}{*}{ 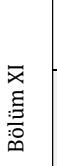 } & $\begin{array}{l}\text { Diy } \\
\text { alog }\end{array}$ & - & - & $\begin{array}{l}2 \\
5\end{array}$ & - & - & - & - & - & - & - & - & $\begin{array}{l}1 \\
6\end{array}$ & - & - & - & - & - & - & $\begin{array}{l}1 \\
7\end{array}$ & - & - & 58 \\
\hline & $\begin{array}{l}\text { Mo } \\
\text { nol } \\
\text { og }\end{array}$ & - & - & 4 & - & - & - & - & - & - & - & - & - & - & - & - & - & - & - & - & - & - & 4 \\
\hline \multirow{2}{*}{ 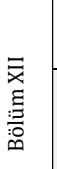 } & $\begin{array}{l}\text { Diy } \\
\text { alog }\end{array}$ & - & - & $\begin{array}{l}3 \\
4\end{array}$ & 7 & $\begin{array}{l}2 \\
1\end{array}$ & - & - & - & - & - & - & - & - & - & - & - & - & - & - & 2 & 9 & 73 \\
\hline & $\begin{array}{l}\text { Mo } \\
\text { nol } \\
\text { og }\end{array}$ & & & $\begin{array}{l}1 \\
0\end{array}$ & . & - & - & - & - & - & - & - & - & - & - & - & - & - & - & - & - & - & 10 \\
\hline \multirow{2}{*}{ 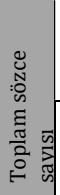 } & $\begin{array}{l}\text { Diy } \\
\text { alog }\end{array}$ & $\begin{array}{l}1 \\
2\end{array}$ & 1 & $\begin{array}{l}3 \\
7 \\
2\end{array}$ & $\begin{array}{l}1 \\
2 \\
5\end{array}$ & $\begin{array}{l}1 \\
7 \\
2\end{array}$ & 1 & 9 & 5 & 1 & $\begin{array}{l}2 \\
4\end{array}$ & 6 & $\begin{array}{l}1 \\
0 \\
1\end{array}$ & 9 & 5 & 0 & 2 & $\begin{array}{l}1 \\
5\end{array}$ & $\begin{array}{l}3 \\
1\end{array}$ & $\begin{array}{l}1 \\
7\end{array}$ & 2 & 9 & 919 \\
\hline & $\begin{array}{l}\text { Mo } \\
\text { nol } \\
\text { og }\end{array}$ & 0 & 0 & $\begin{array}{l}1 \\
1 \\
0\end{array}$ & 8 & 2 & 0 & 0 & 0 & 0 & 5 & 0 & 2 & 4 & 0 & 0 & 0 & 0 & 0 & 0 & 0 & 0 & 131 \\
\hline
\end{tabular}

Tablo 6: Mutfak Çıkmazı'nın öykü düzleminde geçen diyalog ve monologların sayısal verileri

Tablo 6'da yatay eksendeki veriler romanın her bir bölümünde sözcelenmiş sözce öznesi tarafından konuşturulan sözce öznelerinin söylemlerine ve bu söylemlerin bölüm bașına düșen toplamına aittir. Sözce

Adres

RumeliDE Dil ve Edebiyat Araştırmaları Dergisi Osmanağa Mahallesi, Mürver Çiçeği Sokak, No:14/8 Kadıköy - ISTANBUL / TÜRKIYE 34714 e-posta: editor@rumelide.com tel: +90 $5057958124,+902167730616$
Address

RumeliDE Journal of Language and Literature Studies

Osmanağa Mahallesi, Mürver Çiçeği Sokak, No:14/8

Kadıköy - ISTANBUL / TURKEY 34714

e-mail: editor@rumelide.com,

phone: +90 5057958124 , +90 2167730616 
öznelerinin bölümden bölüme değişiklik gösteren sözcelerinin toplamında değişiklik vardır. Yatay eksende gösterilen diyalogların oransal ilișkisi arasında yapılacak bir değerlendirmede ilk bölümün toplam diyalog (sözce) sayısı olan (78) e göre ikinci bölümde (-11) azalma, ikinci bölüme göre üçüncü bölümde (-31) azalma, üçüncü bölüme göre dördüncü bölümde $(+83)$ artma, dördüncü bölüme göre beşinci bölümde $(-56)$ azalma, beşinci bölüme göre altıncı bölümde $(+43)$ artma, altıncı bölüme göre yedinci bölümde $(-15)$ artma, yedinci bölüme göre sekizinci bölümde (-23) azalma, sekizinci bölüme göre dokuzuncu bölümde (+2) artma, dokuzuncu bölüme göre onuncu bölümde $(+20)$ artma, onuncu bölüme göre on birinci bölümde $(-32)$ azalma ve on birinci bölüme göre on ikinci bölümde de $(+15)$ artış görülmektedir. Buradaki verilerden hareketle Tablo 6'da yatay eksende yer alan bölümlerarası toplam diyalog sayılarının artış ve azalış oranlarında farklar görülmektedir: Diyalog bağlamında hareket noktası ilk bölümün toplam sözce oranı olan 78'dir: $(-11>-31<+83>-56<+43>-15>-23<+2<+20>-32<+15)$. Aynı durumu ilgili tablonun yatay ekseninde bölüm başına belirlenen toplam diyalog oranları üzerinden göstermek de mümkündür (78 $>67>36<119>63<106>91>68<70<90>58<73$ ). Burada diyalog sayıları arasında bir fark olabilir, ancak birbiri ardı geçişlerdeki artış ya da azalışta oransal farklar vardır. İlk üç bölümde toplam diyalog (sözce) sayıları azalarak devam ederken $(78,67,36)$ dördüncü bölümde yükselmekte (119), beşinci bölümde düşmekte (63), altıncı bölümde tekrar birden artmakta (106) ve sözce öznelerine diyalog bağlamında verilen söz hakkı farklı oranlarla devam etmektedir.

Yatay eksenin ayrı bir birimi olan monologların oransal ilişkisi arasında da benzer durum ortaya konulabilir. İlk bölümün toplam monolog (sözce) sayısı olan (8) e göre ikinci bölümde (+7) artma, ikinci bölüme göre üçüncü bölümde (+18) artma, üçüncü bölüme göre dördüncü bölümde (-25) azalma, dördüncü bölüme göre beşinci bölümde (+/-0) artma, beşinci bölüme göre altıncı bölümde (+/-0) azalma, altıncı bölüme göre yedinci bölümde (+6) artma, yedinci bölüme göre sekizinci bölümde (-2) azalma, sekizinci bölüme göre dokuzuncu bölümde (-12) azalma, dokuzuncu bölüme göre onuncu bölümde (+11) artma, onuncu bölüme göre on birinci bölümde (-7) azalma, on birinci bölüme göre on ikinci bölümde (+6) artış gözlemlenmektedir. Bölümlerarası monolog sayılarının artış ve azalış oranlarında ortaya konulan farklar burada da bulunmaktadır. Buradaki gösterimin hareket noktası monolog bağlamında ilk bölümün toplam sözce oranı olan 8'dir: $(+7<+18>-25<+0=+0<+6>-2>-12<+11>-7<+6)$. Monologlararası oransal farklılık durumunu yine yatay eksende belirlenen bölüm başına düşen toplam monolog oranları çerçevesinde sunmak olasıdır $(8<15<33>8=8=8<14>12>0<11>4<10)$. Yukarıda yatay eksende diyaloglar için varılan sonuç burada monologlar için de geçerlidir. Bölümlerarası monolog sayılarında düzenli bir artış ya da azalış yoktur, yatay eksende ilk bölüme (8) kez verilen monolog hakkı ikinci bölümde artarak 15'e çıkarken diğer bölümlerde de belirli bir sistematiğe bağlı olmadan orantısız bir şekilde artmakda ya da azalmaktadır.

Yatay eksende biri diyalog diyeri ise monolog olmak üzere iki tür ayrıma gidilmiştir. Çünkü Tablo 3, 4 ve Çizge 6'da da belirtildiği üzere gerçeklik düzleminde yer alan metnin sözceleme öznesi Yücel, kurgusal düzlemdeki sözcüsü olan sözcelenmiş sözce öznesi aracllğıyla öykü düzleminde yarattığı (Ağlayan Akrabalar, Mustafa'nın babası, İlyas Divitoğlu, Emel, Murat, Postacı, Adam, Kasap, Müşteri Kadın, Ev Sahibi Kadın, Güleç Yüzlü Kadın, Selami, Sarışın Mavi Gözlü Kız, Necdet, Aliye, Taksi Şöförü, Kitapçı Akraba, Orhan Bey, Doktor ve Mustafa) gibi sözce öznelerinin bazılarını diyalog ve monolog yöntemiyle iki şekilde konuşturmuştur:

(1) Birden kapısının zili çınladı. Sevinçle fırladı hemen. İçindeki sıkıntı tuzla buz oldu. “Geldi, geri döndü!" dedi kendi kendine.

(2) "Kim o?" diye seslendi (Yücel 2020, 20).

(3) “Sende bir şeyler var," dedi Murat. "Merak ettim, çabuk söyle: ne oldu?

Adres | Address

RumeliDE Dil ve Edebiyat Araşturmalar Dergisi $\quad$ RumeliDE Journal of Language and Literature Studies Osmanağa Mahallesi, Mürver Çiçeği Sokak, No:14/8 $\quad$ Osmanağa Mahallesi, Mürver Çiçeği Sokak, No:14/8 Kadıköy - İSTANBUL / TÜRKIYE 34714 Kadıöy - ISTANBUL / TURKEY 34714 e-posta: editor@rumelide.com e-mail: editor@rumelide.com, tel: +90 505 7958124, +90 2167730616 phone: +90 505 7958124, +90 2167730616 
Divitoğlu içini çekti.“Emel yok artık,” dedi (Yücel 2020, 24).

(4) Gülmesi Murat'ın hoşuna gitti. Hemen sonra da parlak bir düşünce geldi aklına: "Hiç değilse bir-iki gün yemeklerle uğraşır da sıkıntısı dağılır," dedi içinden.

(5) "Belki doğru dürüst beslenemiyor, doğru dürüst yemek yiyemiyor da ondan böyle zayıf. Eskiden böyle değildi," diye düşündü.

(6) “Illk bugün başladım!” diye kekeledi. (Yücel 2020, 34).

(7) “Demek ilk yemeğin?” dedi, çok çekiciydi.

(8) "Bu arada ekmeği alayım bari” diye söylendi.

Örnek olarak verilen alıntılardan harektle $(2,3,6$ ve 7) numaralı diyaloglar (diye seslendi, dedi, diye kekeledi) gibi eylem ifade eden sözcüklerle son bulurken, $(1,4,5$ ve 8) numaralı monologlar (dedi kendi kendine, dedi içinden, diye düşündü, diye söylendi) gibi sözcüklerle bitmektedir. Bu durumla anlatı boyunca karşıllaşılmaktadır. Öykü düzleminde yirmi değişik sözce öznesine konuşma fırsatı verildiği, diyalog şeklinde (919), monolog şeklinde de (131) olmak üzere toplam (1050) konuşmaya rastlanmıştır. Burada konuşturulmayan tek anlatı kişisi, bir kedi olduğu için Aliye'dir, İlyas'ın kedisi Aliye ile anlatıda toplam (21) karakter bulunmaktadır.

Tablo 6'daki dikey eksen ise romanın geneline yayılmış tüm bölümlerinde konuşan sözce öznelerinin konuşmalarının toplamının verildiği eksendir. Dikey eksende bölüm fark etmeksizin bir sözce öznesinin anlatı boyunca üstlendiği diyalog ve monolog şeklindeki konuşmaların toplamını görmek olasıdır. Dikey eksendeki verilere dayanarak metin düzlemindeki sözceleme öznesinin anlatı düzlemindeki sözcelenmiş sözce öznesi vasıtasıyla öykü düzlemindeki sözce öznelerine hem diyalog hem de monolog biçiminde söz vermiştir. Verilen bu sözlerin sayılarını kendi içinde kıyaslamak ve varsa bir takım farklılıkları ortaya koymak mümkündür. Böylece öykü düzlemindeki anlatı kişilerine (sözce özneleri) tanınan diyalog/monolog biçimindeki konuşmaların sıklığı ve varsa aralarındaki oransal farkları tespit etmek mümkün olacaktır.

Tablo 6'daki sözce öznelerinin sırası sözceleme öznesi Yücel'in anlatısını kurgularken belirlediği sıraya göre belirlenmiştir. Bu sıraya göre hareket noktası ilk olarak karş̧laşılan Ağlayan Akrabalara diyalog şeklinde verilen söz hakkı (12) dir. Mustafa'nın Babası (-11), İlyas Divitoğlu (+371), Emel (-246), Murat (+47), Postacı (-171), Adam (+8), Kasap (-4), Müșteri Kadın (-4), Ev Sahibi Kadın (+23), Güleç Yüzlü Kadın (-18), Selami (+95), Sarışın Mavi Gözlü Kız (-92), Necdet (-4), Aliye (-5), Taksi Şöförü (+2), Kitapçı (+13), Akraba $(+16)$, Orhan Bey (-14), Doktor (-15) ve Mustafa (+7). Verilerden yola çıarak Tablo 6'da dikey eksende belirtilen roman boyunca sözce öznelerine düşen diyalog sayılarının artış ve azalış oranlarında farklar görülmektedir. Yani herkese belirli oranda artan ya da azalan toplam söz hakkı verilmemiştir. Buradaki sunumun hareket noktası Ağlayan Akrabalara ait olan toplam (12) diyalogdur: $(-11<+371>-246<+47>$ $-171<+8>-4=-4<+23>-18<+95>-92<-4>-5<+2<+13<+16>-14>-15<+7)$. Buradaki orantisız artış durumunu bir başka şekilde göstermek de olasıdır. Bu seferki gösterim dikey düzlemde anlatı boyunca sözce öznelerine verilen toplam diyalog sayısı üzerinden yapılabilir $(12>1<372>125<172>1<9>5>$ $1<24>6<101>9>5>0<2<15<31>17>2<9$ ). Bu gösterimden de anlaşılacağı üzere roman boyunca sözce öznelerine verilen söz hakkı birbirinden farklıdır.

Yukarıda Tablo 6'ya yönelik yapılan yorumları bir başka çizge ile desteklemek olasıdır. Yalnız bu çizgedeki fark diyalog ve monologların toplam sayısı üzerinden oluşturulacak olmasıdır:

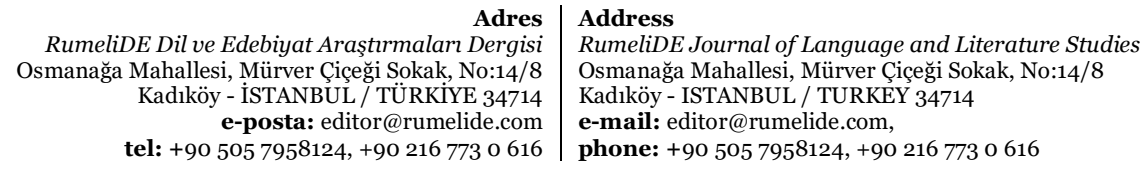




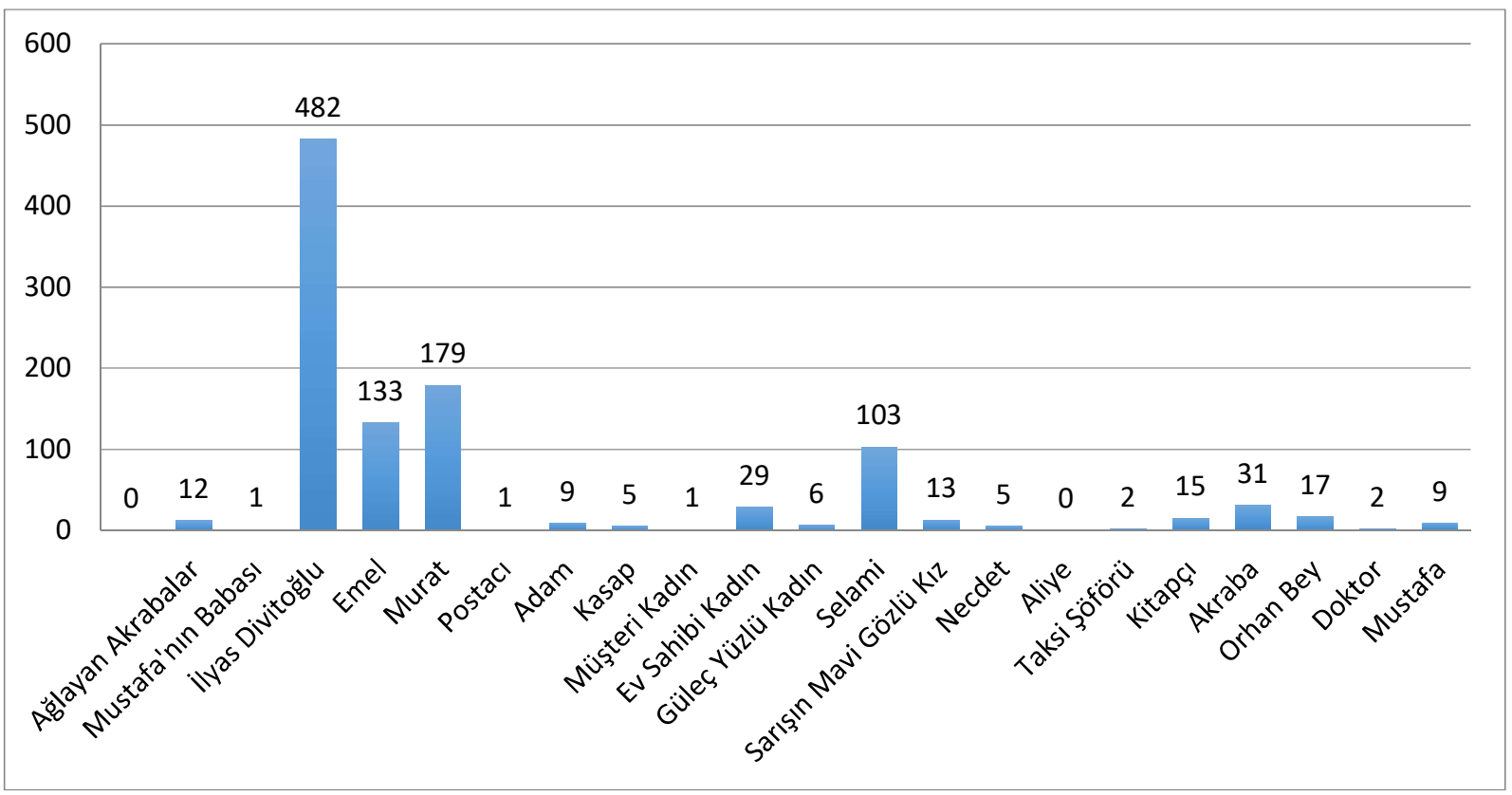

Çizge 7: Mutfak Çıkmazı'nda sözce öznelerinin diyalog/monolog toplam konuşma oranları

Çizge 7'de diyalog ve monolog sayıları birleştirilerek öykü düzleminde hangi sözce öznesinin ne kadar sıklıkla toplam söz hakkı aldığı belirtilmiştir. Bu verilerden hareketle Yücel'in Mutfak Çıkmazı anlatısındaki hakim anlatı kişisine de ulaşmak olasıdır. Anlatı boyunca kendisine (482) defa söz hakkı tanınan İlyas Divitoğlu temel anlatı kişisi, (179) kez söz hakkı verilen Murat, (133) kez söz alan Emel ve (103) kez konuşma hakkı verilen Selami ise temel anlatı kişisi İlyas Divitoğlu'nun hayatında önemli değişikliklere neden olan diğer önemli anlatı kişileri olarak belirmektedir.

Tablo 6'da belirtilen diyalogların hangi sözce özneleri arasında ne kadar sıklıkla gerçekleștiği iletişim döngüsü içinde tek tek ortaya konabilir. Ancak bu çalş̧mada iletişim döngüsü içinde verilen söz hakkı en çok olan temel anlatı kişisi İlyas Divitoğlu'nun diğer sözce özneleri ile olan iletişimindeki sıklı̆ı̆ına ve dolayısıyla diğer sözce öznelerinin de temel anlatı kişisiyle olan konuşmalarının sıklığına yer verilecektir. Anlatının genelinde temel anlatı kişisi İlyas Divitoğlu'nun diğer sözce özneleriyle ve diğer sözce öznelerinin İlyas Divitoğlu'yla ne sıklıkla iletişimde bulunduğunu iletişimin gerçekleştiği uzam ve zaman içinde detaylandırmak olasıdır. Oluşturulacak tabloda İlyas Divitoğlu haricinde sözce öznelerinin sırası Tablo 6'daki sırayla belirtilecektir:

\begin{tabular}{|c|c|c|c|c|c|c|c|c|c|}
\hline \multicolumn{5}{|c|}{$\begin{array}{l}\text { Iletişim durumu I } \\
\text { (Temel anlatı kişinin diğer anlatı kişileriyle olan } \\
\text { iletişim sıklığı) }\end{array}$} & \multicolumn{5}{|c|}{$\begin{array}{l}\text { İletişim durumu II } \\
\text { (Diğer anlatı kişilerinin temel anlatı kişiyle olan } \\
\text { iletişim sıklığı) }\end{array}$} \\
\hline $\begin{array}{l}\text { Sözce } \\
\text { öznesi } \\
\text { (göndere } \\
\text { n) }\end{array}$ & $\begin{array}{l}\text { Sözce } \\
\text { öznesi } \\
\text { (gönderile } \\
\text { n) }\end{array}$ & Yer & Zaman & $\begin{array}{l}\text { Siklı } \\
\mathrm{k}\end{array}$ & $\begin{array}{l}\text { Sözce } \\
\text { öznesi } \\
\text { (göndere } \\
\text { n) }\end{array}$ & $\begin{array}{l}\text { Sözce } \\
\text { öznesi } \\
\text { (gönderile } \\
\text { n) }\end{array}$ & Yer & Zaman & $\begin{array}{l}\text { Siklı } \\
\mathrm{k}\end{array}$ \\
\hline \multirow{2}{*}{$\begin{array}{l}\text { İlyas } \\
\text { Divitoğlu }\end{array}$} & $\begin{array}{l}\text { Ağlayan } \\
\text { Akrabalar }\end{array}$ & \multirow{2}{*}{$\begin{array}{l}\text { Büyük, } \\
\text { eski, } \\
\text { kerpiç }\end{array}$} & \multirow{2}{*}{$\begin{array}{l}\text { İlyas'ın } \\
\text { ölümünd } \\
\text { en sonra }\end{array}$} & \multirow{2}{*}{0} & $\begin{array}{l}\text { Ağlayan } \\
\text { Akrabalar }\end{array}$ & \multirow{2}{*}{$\begin{array}{l}\text { İlyas } \\
\text { Divitoğlu }\end{array}$} & \multirow{2}{*}{$\begin{array}{l}\text { Büyük, } \\
\text { eski, } \\
\text { kerpiç }\end{array}$} & \multirow{2}{*}{$\begin{array}{l}\text { İlyas'ın } \\
\text { ölümünd } \\
\text { en sonra }\end{array}$} & \multirow{2}{*}{0} \\
\hline & $\begin{array}{l}\text { Mustafa'nı } \\
\text { n Babası }\end{array}$ & & & & $\begin{array}{l}\text { Mustafa'n } \\
\text { in Babası }\end{array}$ & & & & \\
\hline \multicolumn{5}{|c|}{$\begin{array}{r}\text { Adres } \\
\text { RumeliDE Dil ve Edebiyat Araşstrmalar Dergisi } \\
\text { Osmanağa Mahallesi, Mürver Ciçeği Sokak, No:14/8 } \\
\text { Kadıköy - İTANBUL / TÜRKIYE } 34714 \\
\text { e-posta: editor@rumelide.com } \\
\text { tel: }+90 \text { 505 7958124, +90 } 216773 \text { o } 616\end{array}$} & \multicolumn{5}{|c|}{$\begin{array}{l}\text { Address } \\
\text { RumeliDE Journal of Language and Literature Studies } \\
\text { Osmanağa Mahallesi, Mürver Ciçeği Sokak, No:14/8 } \\
\text { Kadlköy - ISTANBUL / TURKEY } 34714 \\
\text { e-mail: editor@rumelide.com, } \\
\text { phone: +90 505 7958124, +90 } 216773 \text { o } 616\end{array}$} \\
\hline
\end{tabular}




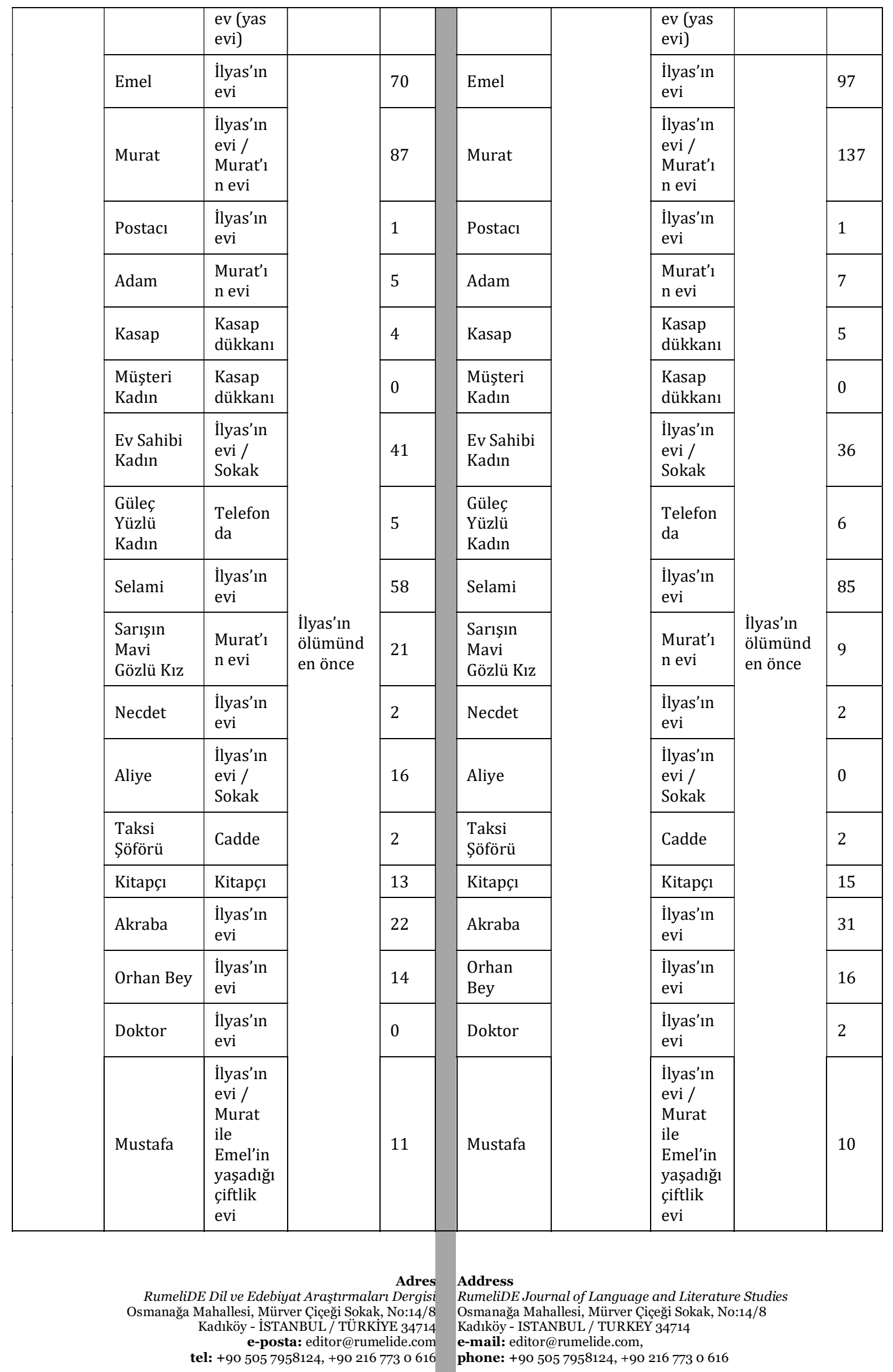




\begin{tabular}{|l|l|l|l|}
\hline Göndere & & Gönderen & \\
n sözce & & sözce & \\
öznesini & 372 & öznelerin & 461 \\
n toplam & & in toplam & 46 \\
sözce & & sözce & \\
sayısı & & sayısı & \\
\hline
\end{tabular}

Tablo 7: Mutfak Çıkmazı'nda sözce öznelerinin temel anlatı kişsi bağlamında birbiriyle olan konuşma sıklı̆̆ı

Tablo 7'de iki farklı iletişim durumu belirlenmiştir. Bunlardan ilki temel anlatı kişisi İlyas Divitoğlu'nun diğer anlatı kişileriyle olan konuşmaları (iletişim durumu I), diğeri ise anlatı kişilerinin temel anlatı kişisi ile olan konuşmaları (iletişim durumu II) şeklindedir. İletişim durumu I'de görüldüğü üzere temel anlatı kişisi İlyas Divitoğlu'nun konuşan bir sözce öznesi olarak öykü düzlemindeki dinleyen sözce özneleri ile arasında gerçekleşen konuşma sıklığı (372) dir. İletişim durumu II'de ise iletişim durumu I de dinleyen durumunda olan sözce özneleri konuşmacı durumundadırlar. Bu sözce öznelerinin toplamda İlyas ile olan konuşmaları (461) dir. İletişim durumu I'de gönderen konumunda olan sözce öznesi İlyas Divitoğlu tarafından üretilen sözcelerin yeri, zamanı ve alıcısı da duruma göre değișmektedir. Bu bağlamda konuşan sözce öznesi (gönderen), dinleyen sözce öznesi (gönderilen), sözcenin üretim yeri ve zamanı hakkındaki bilgiler tabloda özetle verilmiştir.

Tablonun yorumlanmasında $(\rightarrow)$ göstergesi gönderen konumundaki sözce öznesinin gönderilen konumundaki sözce öznesine yönelik konuşmaları, $(\leftrightarrow)$ gönderen ve gönderilenin karşılıklı konuşmaları, (Ø) göstergesi ise gönderen ve gönderilen sözce özneleri arasında gerçekleşmeyen konuşmaları (iletişimsizlik durumu) belirtmek için kullanılacaktır

Tablo 7, iletişim durumu I'de (gönderen) İlyas Divitoğlu'nun bazı (gönderilen) sözce özneleriyle doğrudan ya da dolaylı bir iletişimi yoktur. Bunların başında (Ağlayan Akrabalar) gelmektedir (İlyas Divitoğlu Ø Ağlayan Akrabalar). Bunun nedeni ise Tablo 6'nın dikey ekseninde birinci bölümde toplam (12) diyalog şeklinde verilen konuşmaların yas evinde (yer) İlyas'ın ölümünden sonra (zaman) Ağlayan Akrabalar (sözce özneleri) arasında gerçekleșmesidir (Ağlayan Akrabalar $\leftrightarrow$ Ağlayan Akrabalar):

Ama orada, o büyük, o eski, o kerpiç evde, herkes yalnız bir yitiğe ağlıyor, herkes “ílyas!” diye inliyordu. Kocamıș kadınlar, gelinler, kızlar "Güzel İlyas, yiğit İlyas, bir İlyas, büyügüumüz, baştacımız, bir İlyas!" diyorlardı. onlar ağlıyorlardı. "İlyas" diyor, başka bir şey demiyorlardı. [...] "Biz ne güne duruyorduk, İlyas?” diyorlardı (Yücel 2020, 14).

Benzer bir durum da İlyas Divitoğlu ve (Mustafa'nın Babası) ile ilgilidir. Tablo 6'da birinci bölümde her ne kadar bu sözce öznesine ait (1) adet sözce varsa da Tablo 7'de bu sözcenin iki sözce öznesi arasında olmadığı görülmektedir (İlyas Divitoğlu Ø Mustafa'nın Babası). Çünkü iki sözce öznesi arasındaki iletişim döngüsü (Ağlayan Akrabalar) ve (Mustafa'nın Babası) arasında gerçekleşmektedir (Ağlayan Akrabalar $\leftrightarrow$ Mustafa'nın Babasi):

Bazı bazı gözyaşları kuruyordu. Kederle, umutsuzlukla birbirlerine bakıyorlardı. "Mezarı çok büyük olacak!" diyordu biri, birdenbire coşuyordu: "Mezarı çok büyük olacak, türbe gibi... Nerden baksan görünecek... Ev, dükkân, tarla demeyip satacağız, bu mezarı yaptıracağız!” Evet, öyle, yaptırtacaklardı, herkes aynı karşılığı veriyordu: "Yaptıracağız!" Yaptırtacaklardı elbet, sorun yoktu, her şeyde anlaşıyorlardı. "Öcünü de alacağız İlyas'ın, Mustafa'yı delik deșik edeceğiz," diyorlardı. Mustafa'nın babası da aynı düşüncedeydi. "Evet, ele geçer geçmez...” diyordu (Yücel 2020 14-15).

Temel anlatı kişisi çerçevesinde yukarıda sözü edilen iletişimsizlik olguları (iletişim durumları I) ve (iletişim durumları II) her iki sütun için de geçerlidir. Ne İlyas Divitoğlu'nun Ağlayan Akrabalar ve Mustafa'nın Babası'yla ne de Ağlayan Akrabalar ve Mustafa'nın Babası'nın İlyas Divitoğlu’yla gönderen ve

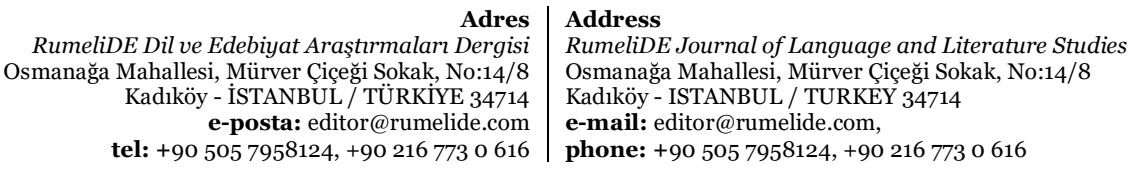


göndederilen olarak iletişim döngüsü içinde doğrudan bir ilişkisi yoktur (İlyas Divitoğlu $\emptyset$ Ağlayan Akrabalar, Mustafa'nın Babası / Ağlayan Akrabalar, Mustafa'nın Babası Ø İlyas Divitoğlu).

Bir diğer iletişimsizlik durumu da gönderen sözce öznesi İlyas Divitoğlu ve müşteri olduğu kasapta aynı anda bulunan başka bir müșteri (Kadın Müşteri) ile ilgilidir (İlyas Divitoğlu Ø Kadın Müşteri). Bunun nedeni ise gönderen sözce öznesinin bulunduğu mekanda kuracağı iletişimin hedefinde ilgili mekanın sahibi olmasıdır. Bu durumu bir sonraki gönderen (İlyas Divitoğlu) ile gönderilen (Kasap) arasında görmek mümkündür (İlyas ↔ Kasap):

İlkin kasaba gitti. Ak gömleği leş gibi bir adam et kesiyor, et çekiyor, et tartıyordu. [...]

"Beyefendi, beyefendi!" diye seslendi ardından. "Buyur, beyefendi, ne istiyorsun?"

"Yarım kilo et," dedi Divitoğlu (Yücel 2020, 29-30).

Kasap tarafından ilk sözcenin üretimi İlyas'ı dinleyen sözce öznesi konumuna getirmiştir (Kasap $\rightarrow$ İlyas). İlyas' 1 cevabı ise Kasabı dinleyen konumuna getirmiştir (İlyas $\rightarrow$ Kasap). Dolayısıyla her iki sözce öznesi arasında karşılıklı bir iletişim edimi gerçekleşmiştir (İlyas $\leftrightarrow$ Kasap).

Aynı durum (Müşteri Kadın) ile (Kasap) arasında kasap dükkanında (yer) gün içinde (zaman) olmasıdır:

İlkin kasaba gitti. Ak gömleği leş gibi bir adam et kesiyor, et çekiyor, et tartıyordu. Orta yaşlı kadınlarla doluydu dükkânın içi. Hep birden konuşuyorlardı. Kimileri gülümsüyordu. Biri de kasapla tartışmaya başladı. [...] "Ben beyden önceydim," dedi kadının biri.

Ama kasap aldırmadı (Yücel 2020, 29-30).

Konuşan sözce öznesi olarak araya giren Müșteri Kadın'nın konuşmaları ne İlyas Divitoğlu ne de Kasap tarafından dikkate alınmıştır ve bu sözce özneleri arasındaki iletişim daha başlamadan bitmiştir (Müşteri Kadın Ø İlyas Divitoğlu / Müşteri Kadın $\rightarrow$ Kasap Ø Müşteri Kadın).

Benzer durumu farklı bir haliyle Doktor ve İlyas Divitoğlu arasında görmek olasıdır:

Aradan bir saat bile geçmeden, Murat başucundaydı. Doktoru da getirmişti. Doktordan hiçbir şey gizlenmezdi: Divitoğlu gösterilmez yerini gösterdi.

"Evet, hanım haklı, iyi anlamış," dedi adam. bir reçete yazdı.

"Bundan böyle ne içki ne sigara... Yoksa gene yataklara düşerseniz böyle," dedi. Parasını alıp gitti (Yücel $2020,136)$.

Burada da İlyas ve Doktor arasında karşllıklı bir konuşma tam olarak yoktur (Doktor $\rightarrow$ İlyas $\varnothing$ Doktor). Doktor gelir İlyas'a bakar ve gekenleri söyler gider. İlyas'ın Doktor'la bir şey konuşmaması belki hastalığının vermiş olduğu rahatsızlıkta belki de rahatsızlığının bulunduğu yeri verdiği çekingenlikten olabilir. Ancak sonuç olarak İlyas, Doktor'la iletişime geçmez ve gönderilen sözce öznesi durumunda kalır.

Benzer, yani tek taraflı konuşma durumunun İlyas ve Aliye arasında da geçtiği görülür. Konuşan sözce öznesi (İlyas Divitoğlu $\rightarrow$ Aliye):

“Gel artık, Aliye," dedi. “Gel, evimize dönelim.” (88)

“Hangisini yapsak dersin, Aliye?” diye sordu. Aliye'den ses çıkmadı (106).

“Aliye! Aliye!" diye seslendi.

"Hangi Aliye? Aliye kim?"

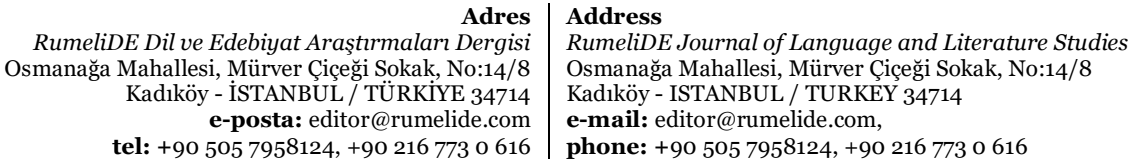


Tablo 7'deki verilerden hareketle temel anlatı kişisi İlyas Divitoğlu'nun anlatı boyunca öykü düzleminde bulunan diğer kişilerle olan iletişimini, iletişimdeki sıklığını ve bu durumun karşıt anlatı kişilerinde de ne sıklıkta olduğu incelenmiștir. Burada hem dinleyici hem de konuşmacı konumunda olan sözce öznelerinin birbiriyle olan konuşmalarının (ürettikleri sözcelerin) sıklığını görmek olasıdır.

\section{Sonuç}

Bu çalışmada akademisyen-yazar Tahsin Yücel'in Mutfak Çıkmazı isimli romanı söylem göstergebilimi çerçevesinde incelenmiştir. Çalışmanın temel amacı, kapalı bir sözce/söylem olan romanın hangi süreçlerden geçerek nasıl anlamlı bir bütün haline yani sözceye dönüştüğünü sayısal verilerle birlikte ortaya koymaktır. Bunun için çalışmanın çözümleme aşaması üç alt başlıkta gerçekleştirilmiştir. İlk alt bölümde (a) inceleme nesnesinin yapısal olarak nasıl düzenlendiğine bakılmıștır. Burada metnin sayfa yapısından sıra düzenine kadar bazı belirlemelerde bulunulmuştur. Öncelikle metnin kendi içinde nasıl bölümlendiği, hangi bölüme kaç sayfa ayrıldığı, bölümlerarası sayfalarda bırakılan bölüm başı ve bölüm sonu sayfa (satır) boşluk oranları ve bu oranların kendi arasında sistemli olarak değişime uğrayıp uğramadığı araştırılmıştır. Elde edilen verilere göre her bir bölüm için ayrılan sayfa miktarında orantısız artış ve azalışlar tespit edilmiştir. Benzer durum her bölümün sonunda bırakılan sayfa boşluk oranı için de geçerlidir. Bu yüzden hem bölümlere ayrılan sayfa miktarında hem de bölümlerin sonunda bırakılan sayfa boşluk oranında düzensiz değişikliklere rastlanmıştır. Ancak aynı durumu bölüm başlarında bırakılan sayfa boşluk oranı için söylemek olası değildir. Çünkü metnin ilk bölümünden son bölümüne kadar her bölümün başlangıcı için ayrılan sayfa boşluk oranında herhangi bir değişim, düzensizlik ya da orantısızlık gözlenmemiştir. Her bir aşamada elde edilen veriler aynı kategorideki diğer verilerle büyüklü/küçüklük durumuna göre ilişklilendirilmiş ve mümkün olduğu yerlerde çizge ve tablolarla gösterilmiştir.

Çözümleme kısmının ikinci (b) aşamasında ise Mutfak Çıkmazı romanının sözceleme durumuna detaylı bir şekilde yer verilmiştir. Sözceleme durumu çerçevesinde metnin oluşumuna katkı sunan yazar, yer ve zaman sözceleme kuramı çerçevesinde betimlenmiştir. Sözceleme durumunun betimlenmesi çalışmayı daha da ileriye taşımış ve ilgili sürece bağlı olarak hem anlatılanın hem de anlatıcının konumu kuramsal açıdan ele alınmıştır. Bu sayede çalışma gerçeklik düzleminde elde edilen verilerden hareketle kurgusal düzleme doğru derinleştirilmiştir. Bu bakımdan inceleme nesnesi hem gerçekli hem de kurgusal olmak üzere iki farklı boyutta incelenmiştir. Bu süreçte araştırma nesnesi metin, anlatı ve öykü bağlamlarında romandan örneklerle incelenmiş ve ayrıntılı bir şekilde sözceleme durumuyla ilişkilendirilmiş bilgiler ortaya çıkarılmıştır.

Çözümlemenin son kısmında ise (c) romanın öykü düzlemine odaklanılmış ve sözce öznelerinin sözceleri bağlamında birbiriyle olan ilişkilerine, ürettikleri sözcelerin sıklık derecelerine hem bölümler hem de anlatı kişileri bağlamında bakılmıştır. Bu çerçevede Mutfak Çıkmazı'nın öykü düzleminde hangi anlatı kişisinin ne sıklıkta diyalog ve monolog șeklinde sözcesinin olduğu, anlatı boyunca ilgili diyalog ve monologların sayısal değerlerinin ne olduğu, bu değerlerin bölüm başına ve anlatı kişisi başına düşen oranı gibi önemli bilgilere ulaşılmıştır. Daha sonra da elde edilen verilere dayanılarak öykü düzlemindeki sözce öznelerinin hem konuşmacı hem de dinleyici kimlikleriyle birbiriyle iletişimindeki yerine temel anlatı kişisi merkezinde bakılmıștır.

Sonuç olarak söylemin izlerini sürme niyetinde olan bu tür bir göstergebilim çalışması sözceleme kuramının kendisine olan katkısını inkar etmez ve bu katkıyla birlikte bir söylem göstergebilimine dönüşür. Bu çerçevede inceleme nesnesinin nasıl bir sözceye/söyleme dönüştüğüne yönelik süreçler metin, anlatı ve öykü katmanlarında incelenmiş ve edebi bir eser olan araştırma nesnesinde söylemi kuran oluşturucu

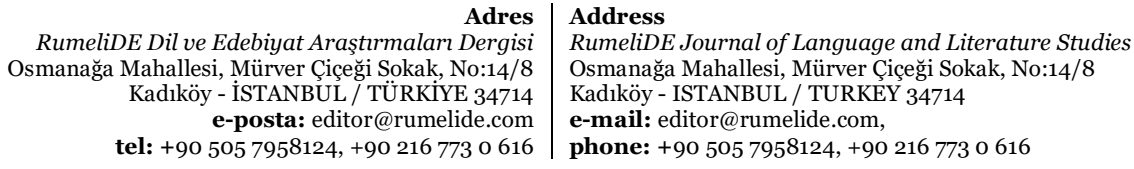


ögelerin izleri hem gerçeklik hem de kurgusal düzlemde sayısal verileriyle birlikte betimlenmiştir. Genel olarak üretilen kapalı sözcelerin (metin) içeriğine bakıldığında farklı metin tiplerinin birbiriyle etkileşim halinde olduğu bilinmektedir. Bazen söyleşimsel metin türünün özellikleri anlatısal bir metinde bazen de anlatısal metin türünün özellikleri ise söyleşimsel bir metinde görülebilir. Yapılan bu çalışmada da, diyalog ve monologların bölüm ve sözce öznesi başına düşen konuşma sıklıklarına bakıldığında Yücel'in Mutfak Çıkmazı'nın anlatısal bir metin olma özelliğinin yanı sıra söyleşimsel bir metin olduğu yargısına da varılabilir. Çünkü söyleşimsel anlatı türüne kanıt olarak karşılıklı konuşma (diyalog) bağlamında sözce öznelerine ait toplam (939), monolog bağlamında ise toplam (131) konuşmaya rastlanmıştır. Monologların zaman zaman her ne kadar anlatının hızını kesmek ya da düşürmek gibi bir etkisi olsa da sözce özneleri arasında geçen diyaloglar ve sıklıkları hesaba katıldığında burada hem metnin hareketliliği hem de anlatısallığı açısından bir çeşitlilik söz konusudur. Bu bağlamda sözceleme öznesi Yücel'in ürettiği sözcesi/söyleminde anlatısallık ve söyleşimsellik drumlarını da içi içe görmek mümkündür.

\section{Kaynakça}

De Saussure, F. (1998). Genel Dilbilim Dersleri. (Çev. B. Vardar). İstanbul: Multilingual.

Günay, V. D. (2013). Söylem Çözümlemesi. İstanbul: Papatya.

Günay, V. D. (2018). Bir Yazınsal Göstergebilim Okuması: Kuyucaklı Yusuf. İstanbul: Papatya Bilim.

Greimas, A. J. \& Joseph, C. (1982). Semiotics and language: An Analytical Dictionary. (Çev. L. Crist, D. Patte). Bloomington: Indiana University Press.

Kalelioğlu, M. (2020). Act of signification from narratology to semiotics within the scope of interdisciplinary approach.

RumeliDE Dil ve Edebiyat Araştırmaları Dergisi, (Ö8), 97-113. DOI: 10.29000/rumelide.814075.

Kıran, A. \& Kıran, Z. (2011). Yazınsal Okuma Süreçleri. (4. Baskı). Ankara: Seçkin.

Kıran, Z. \& Kıran, A. (2013). Dilbilime Giriş. (4. Baskı). Ankara: Seçkin.

Rifat, M. (2011). Metnin Sesi. (2. Baskı). İstanbul: Türkiye İş Bankası.

Sığırcı, İ. (2017). Göstergebilim Uygulamaları. Metinleri, Görselleri, Olayları ve Sanat Yapıtını Okuma. (2. Baskı). Ankara: Seçkin.

Seymour, C. (1978). Story and Discourse: Narrative Structure in Fiction and Film. Ithaca and London: Cornell University Press.

Yücel, T. (2015). Yapısalcılık. (3. Baskı). İstanbul: Can Sanat.

Yücel, T. (2020). Mutfak Çılkmazı. (6. Baskı). İstanbul: Can Sanat.

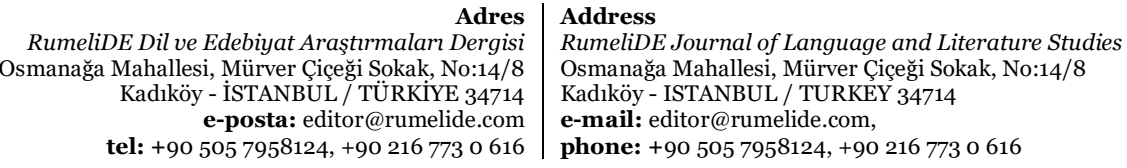

